Semin Cell Dev Biol. 2019 November ; 95: 42-53. doi:10.1016/j.semcdb.2019.01.005.

\title{
Neural stem cell niche heterogeneity
}

Julia P. Andreottia , Walison N. Silva ${ }^{a}$, Alinne C. Costa ${ }^{a}$, Caroline C. Picolia, Flávia C.O. Bitencourt $^{a}$, Leda M.C. Coimbra-Campos ${ }^{a}$, Rodrigo R. Resende ${ }^{b}$, Luiz A.V. Magno ${ }^{c}$, Marco A. Romano-Silvac ${ }^{c}$, Akiva Mintz ${ }^{\mathrm{d}}$, Alexander Birbraira,d, ${ }^{\text {, }}$

aDepartment of Pathology, Federal University of Minas Gerais, Belo Horizonte, MG, Brazil

${ }^{b}$ Department of Biochemistry and Immunology, Federal University of Minas Gerais, Belo Horizonte, MG, Brazil

'Department of Mental Health, Federal University of Minas Gerais, Belo Horizonte, MG, Brazil

${ }^{\mathrm{d}}$ Department of Radiology, Columbia University Medical Center, New York, NY, USA

\begin{abstract}
In mammals, new neurons can be generated from neural stem cells in specific regions of the adult brain. Neural stem cells are characterized by their abilities to differentiate into all neural lineages and to self-renew. The specific microenvironments regulating neural stem cells, commonly referred to as neurogenic niches, comprise multiple cell populations whose precise contributions are under active current exploration. Understanding the cross-talk between neural stem cells and their niche components is essential for the development of therapies against neurological disorders in which neural stem cells function is altered. In this review, we describe and discuss recent studies that identified novel components in the neural stem cell niche. These discoveries bring new concepts to the field. Here, we evaluate these recent advances that change our understanding of the neural stem cell niche heterogeneity and its influence on neural stem cell function.
\end{abstract}

\section{Keywords}

Neural stem cell; Niche; Microenvironment; Maintenance; Plasticity

\section{Introduction}

Since the time of Santiago Ramón y Cajal, for almost a century, the adult nervous tissue had been mistakenly considered invariable in all animals. This concept started changing, when, initially, it was discovered that invertebrates are not included in this conception, especially during metamorphosis [1]. Later, also lower vertebrates, such as birds during their song learning process, were described to possess plasticity in the central nervous system [2].

"Corresponding author at: Department of Pathology, Federal University of Minas Gerais, Belo Horizonte, MG, Brazil. birbrair@icb.ufmg.br (A. Birbrair).

Disclosures

The authors indicate no potential conflicts of interest. 
Finally, in mammals, while the vast majority of neurons are generated in utero [3], at the end of last century, neural stem cells were described in specific regions in the adult brain [4].

Neural stem cells are undifferentiated neural cells that are defined based on their extensive replicative potential, their ability to differentiate into multiple central nervous system neuronal and glial cell types, and their capacity for long-term self-renewal. Albeit the high proliferative capacity is a hallmark of stemness, a unique characteristic of neural stem cells, comparing to other central nervous system cells, is their capability to stay dormant for very long periods, providing a reserve pool of cells available for tissue regeneration and cell replacement throughout life [5,6].

In the adult mammalian brain, there are at least two areas that are neurogenic and contain a reservoir of neural stem cells: the subgranular zone in the hippocampal dentate gyrus and the subventricular zone around the lateral ventricles [7]. Interestingly, the hypothalamus has been recently identified as a possible third neurogenic area in the mammalian brain $[8,9]$ (Fig. 1). Hypothalamic neurogenesis has been associated to the regulation of body weight homeostasis and the control of energy balance [10,11]. Quiescent and activated neural stem cells coexist within these neurogenic regions generating new cells throughout life [12-14]. The role of adult neurogenesis goes also beyond the simple replacement of cell loss in the adult central nervous system, as it has been associated with multiple brain functions.

Adult neural stem cells in the dentate gyrus originate intermediate progenitor cells [15], which go through fast, but limited, divisions before they exit the cell cycle and differentiate into mature astrocytes and neurons. This process has been demonstrated to be crucial in memory formation and behavioral performance [16]. Interestingly, physical exercise, which promotes learning and memory, activates subgranular zone neurogenesis [17-19]. Within the adult subventricular zone, activated neural stem cells form neuroblasts which travel through the rostral migratory stream to the olfactory bulb, where they originate periglomerular and granule mature neurons [20]. These neurons formed in the olfactory bulb are involved in olfactory learning during adulthood [21,22]. Adult neural stem cells also originate NG2-glia cells that disperse to the white and gray matter, which can generate corpus callosum oligodendrocytes or olfactory bulb interneurons [23-25].

It is still unclear how neural stem cells are actively maintained throughout life, and what are the cellular interactions, molecular cascades, and accountable cell and non-cell-autonomous signals that regulate neural stem cell behavior. Tissue microenvironments are very complex, being composed of multiple cell types with a variety of cues that are constantly released [26-32, 186, 187]. Understanding the signaling mechanisms that determine neural stem cell fate will be crucial for the success of clinical applications targeting these cells. Recent studies using genetically modified mouse models indicate that the fate of neural stem cells is finely regulated by changes in the surrounding microenvironment, also termed niche, in which they reside. These changes are dictated by both extrinsic (for instance, physical activity, stress, environmental enrichment, or aging) and intrinsic (for instance, cytokines, growth factors, hormones, or neurotrophins) factors [33]. Therefore, decisions regarding neural stem cell self-renewal, activation or differentiation are dependent on the interaction with constituents from their niche. The deregulation of those microenvironmental regulatory 
mechanisms may cause dysfunction of neural stem cells, leading to neurological disorders [34].

The discovery of neural stem cells in the adult brain provided us with a promising target for central nervous system disease therapies [35]. A large number of investigations were already performed in order to understand the behavior of these cells in the adult brain; nevertheless, the best is yet to come. Recently, several components of the neural stem cell niche have been identified, regulating neural stem cell activity by supplying various signals. In this review, we present an overview of the current knowledge on the variety of brain components in the neurogenic niche and their effects on neural stem cells.

\section{Heterogeneity of neural stem cells}

Neural stem cells are not equally plastic homogeneous cells, but rather a combination of distinct subpopulations [36]. This concept needs to be considered to fully understand the relationship between adult neural stem cells and their niches. Neural stem cells display regional heterogeneity possibly acquired from their embryonic origin and niche patterning [188]. Viral lineage-tracking and recombinase-based fate mapping experiments of cell populations in distinct dorso-ventral or rostro-caudal regions of the adult subventricular zone revealed that a mosaic of neural stem cells are distributed in diverse domains, correlating with specific regional expression of particular transcription factors [37]. This subventricular zone regional identity of adult neural stem cells appears as early as embryonic day E15.5 [38]. Nevertheless, it remains poorly explored how exactly adult neural stem cells become regionally specified. Interestingly, heterotopic transplantation studies suggest that neural stem cell identity is partially a cell intrinsic characteristic, as neural stem cells, after transplant to a different neurogenic area, keep their regional identity and continue to produce the same progeny as in the original position [39]. Additionally, neural stem cells undergo changes in chromatin structure, mRNA, and noncoding RNA levels that make them more or less sensitive to external signals over short time periods [40-42].

The unique genetic signature reflects the regional identity of neural stem cells. Importantly, the heterogeneity revealed at the molecular level may translate into singular functional differences. Both quiescent and activated neural stem cells are present within the neurogenic niches [5]. Multiple molecular markers were proposed to be used to distinguish neural stem cell subsets such as CD15 [43], CD133 [44], Sox1 [45], Nestin [46-48], and EGFR [49]. More recently, the possibility of analyzing multiple molecular markers in combination (GFAP, EGFR, CD133, Nestin, CD9, CD81, CD24, and VEGF), by the use of transgenic mice, flow cytometry, and single cell RNAseq, revealed the complexity within the neural stem cells population [50-53]. These differences within neural stem cells possibly reflect transcriptional networks and signaling set points unique to subsets of neural stem cells. Although the regional identity of neural stem cells has been mainly typified in mouse models, analyses in the primate brain have also revealed heterogeneity of subventricular zone neural stem cells which declines with aging [54]. Nevertheless, our knowledge on the human neural stem cells heterogeneity remains very limited. In the future, deciphering the functional consequences of adult neural stem cell heterogeneity will be crucial to understand brain functioning in physiologic and pathologic conditions. 
Although neural stem cell heterogeneity has not been exhaustively explored yet in the adult dentate gyrus, subpopulations of neural stem cells with different morphologies and behaviors have been described in this neurogenic area $[55,56]$. The dentate gyrus is anatomically subdivided into temporal and septal regions [57]. Remarkably, these two areas differ in their functionality and molecular composition [58]. There is a gradient in the expression of several molecules throughout the dentate gyrus. For instance, Wnt inhibitor Frizzled-related protein 3 is highly expressed in the temporal region in comparison with the expression in the septal area [59]. Interestingly, genetic deletion of this gene results in activation of neural stem cells in the temporal region, indicating a potential molecule that creates spatial heterogeneity in the adult dentate gyrus [60]. Moreover, neurogenesis in the septal region, in comparison with the temporal region, is faster [61]; while the density of neural stem cells in the temporal region is lower than in the septal region [62].

Unfortunately, still there are no defined molecular markers to distinguish neural stem cell subtypes in vivo.

In a recent elegant study, Song's group used morphological differences to separate subgranular zone neural stem cells into two subsets [56]. The rarer neural stem cells, termed type p cells, have shorter and more branched processes compared to the more abundant type a cells. Genetic fate mapping revealed that type a cells can originate type p cells, therefore being hierarchically superior to type $\mathrm{p}$ cells, while type $\mathrm{p}$ cells did not proliferate. Nevertheless, the heterogeneity within the population of type a cells was not yet explored, and remains unknown whether all type a cells can form type p cells. These data suggest that there are different neural stem cell populations in the adult dentate gyrus. Single cell RNAseq analyses will permit high throughput data collection that may reveal whether these cell populations can be further subdivided into multiple subsets with distinct functions, reacting differently to niche signaling.

Novel tools should be generated to determine what constitutes a population of neural stem cells versus transition cellular states. As neural stem cells also present microenvironment dependent plasticity, future studies should explore how neural stem cells heterogeneity affects cell competition within the same niche, and whether such heterogeneity allows adaptation to distinct microenvironmental cues. Defining the signals that can influence different neural stem cells populations behavior will have important implications for developing therapeutic strategies for neural disorders based on the mobilization of endogenous neural stem cells.

Very little is known about the extrinsic signals that regulate neural stem cells subpopulations. It is still not completely known whether and how the neurogenic microenvironments differ. The functional heterogeneity of neural stem cells points to the potential for matching heterogeneity of influences from the niche that support the behavior of these neural stem cell subsets. The remainder of this review will focus on the neural stem cell niche heterogeneous components. 


\section{Cerebrospinal fluid in the neural stem cell niche}

Neural stem cells in the subventricular zone are in direct contact with the cerebrospinal fluid-filled ventricles [63]. The cerebrospinal fluid is a reservoir of signaling molecules, which is modulated by external factors. Subsequently, neural stem cells receive cues from this fluid, allowing them to sense external changes. The cerebrospinal fluid is essential for the development and maintenance of the central nervous system [64-66]. It contains multiple trophic factors essential for the maintenance and proliferation of neural stem cells, including trophic factors and neuroendocrine peptides [67-75]. Cerebrospinal fluid also regulates neural stem cell behavior via hydrostatic forces [76]. Now, in a recent article in Cell Stem Cell, Petrik and colleagues reveal a molecular sensor present in neural stem cells which detects cerebrospinal fluid flow [77] (Fig. 2). The authors demonstrated that neural stem cells are highly enriched with the epithelium sodium channel [77]. Petrik and colleagues investigated the role of the epithelium sodium channel in neural stem cells by using state-of-the-art techniques, including subventricular zone whole mounts, sophisticated Cre/loxP techniques in vivo, confocal microscopy, and electrophysiological recordings. These experiments showed that epithelium sodium channel is essential for neural stem cells proliferation in vitro [77]. Strikingly, genetic deletion of epithelium sodium channel specifically from neural stem cells reduced the number of neural stem cells and inhibited their activation and proliferation, leading to reduction of neuroblasts derived from these neural stem cells [77]. Interestingly, artificial cerebrospinal fluid flow promoted neural stem cells proliferation in the whole mount subventricular zone through epithelium sodium channels. As when these channels were specifically blocked, the effect on neural stem cells proliferation disappeared [77]. Additionally, Petrik and colleagues demonstrated that within neural stem cells epithelium sodium channels induce sodium and calcium influx in response to cerebrospinal fluid flow [77].

This study reveals a novel mechanism of the interaction between cerebrospinal fluid flow and neural stem cells, nonetheless several questions remain unanswered. Conditional gene manipulation strategies, as the ones used in this study, offer a powerful tool to study the role of specific genes in particular cell populations [78]. Nevertheless, this type of studies also may have their caveats. The main findings from this study are based on the data obtained from tamoxifen-inducible Glast promoter driven CreER-LoxP system. In this mouse model, cells produce the recombinase based on their expression of the glutamate aspartate transporter (Glast). Albeit neural stem cells express Glast, they are not the only cells in the brain that express this gene, and, more importantly, other cells present in the subventricular zones will produce the recombinase in those mice as well, such as pericytes [79]. Therefore, it remains to be answered whether the genetic ablation of epithelium sodium channel in Glast-expressing cells may contribute to the behavior of neural stem cells indirectly in the subventricular zone. Another question that remains open, is, as discussed above, that neural stem cells are heterogeneous in their niche. Future studies should examine whether epithelium sodium channel is crucial to sense the cerebrospinal fluid flow in all neural stem cells or in a specific sub-population. It remains also unknown whether the importance of this channel in sensing the cerebrospinal fluid flow is restricted to a certain time period throughout life, and when during development this channel becomes crucial. 
Importantly, it still needs to be explored whether the role of the epithelium sodium channel on neural stem cells id altered in neurodegenerative disorders. Are some of the defects in neurogenesis seen in brain pathologies due to altered sensing of the cerebrospinal fluid flow by neural stem cells? As neural stem cells are key in neural regeneration, is the neurogenic control by the cerebrospinal fluid flow transmitting physiological and pathological conditions of the brain to the neural stem cells?

\section{Autocrine regulation in the neural stem cell niche}

Multiple signaling molecules identified in the neurogenic niche regulate the behavior of neural stem cells, such as neurotransmitters, growth factors, and membrane-associated ligands. Most of these molecules are derived from various cellular components of the neural stem cell niche, and act in a paracrine, non-cell autonomous, way. Whether neural stem cells can be regulated by factors derived from themselves remains unknown. Now, in a recent article in Cell Stem Cell, Zhou and colleagues show that neural stem cells in the subgranular zone can regulate their own quiescence in an autocrine manner [80] (Fig. 3). Interestingly, based on a single neural stem cell RNAseq analysis from the same group [81], the authors found that lactadherin, also known as Mfge8 or SED1, is highly expressed in quiescent neural stem cells from the dentate gyrus. Zhou and colleagues used state-of-the-art techniques, including sophisticated Cre/loxP technologies, in vivo lineage-tracing, and confocal microscopy to determine the role of lactadherin in neural stem cells in the subgranular zone. Their results demonstrated that lactadherin is required to promote the maintenance and quiescence of neural stem cells in the hippocampus. Strikingly, genetic ablation of lactadherin from neural stem cells led to decreased density of quiescent neural stem cells in the adult subgranular zone [81]. Furthermore, short-term fate tracking upon deletion of lactadherin in quiescent neural stem cells revealed a significant increase in proliferating neural stem cells, indicating that lactadherin blocks neural stem cell activation and proliferation. Finally, Zhou and colleagues explored the mechanism by which lactadherin promotes neural stem cell quiescence, demonstrating that it is via suppression of mTOR1 pathway [80]. This work provides a novel role for lactadherin in the hippocampus, and reveals that neural stem cells are also crucial in the formation of their own niche.

Zhou and colleagues examined neural stem cell as a homogeneous cell population in their study [80]. Nevertheless, as mentioned above, it would be interesting to explore whether lactadherin is restricted to a neural stem cell subset. Moreover, the mouse model that was used to study neural stem cells (Gli1-CreERT2 mice) is not specific to neural stem cells, as it presents recombinase activity also in perivascular cells [82-84]. Therefore, future experiments will reveal whether lactadherin is an exclusively autocrine signal or if it may derive from other niche components as well. Additionally, it remains unknown whether in other neurogenic niches besides the hippocampus lactadherin has a similar role.

\section{Perivascular neural stem cell niche}

Stem cells from multiple organs are located in a very close position to the vascular network, including neural stem cells, implicating that blood vessels are an integral constituent of the stem cell niche $[24,85-91]$. Interestingly, the neurogenic regions are more vascularized than 
not-neurogenic areas in the brain [91-93]. The vasculature in these regions is more permeable, and the blood flow in slower, suggesting that there is facilitation in the access of blood-derived signals to the neural stem cells $[24,91,92,94]$. In both main neurogenic regions, subventricular and subgranular zones, proliferating neural stem cells are in close physical proximity to the vasculature than other niche cellular components $[89,86-$ $91,95,96]$. Importantly, transplanted neural stem cells also preferentially associate to blood vessels [97]. Although some studies correlate angiogenesis in the neural stem cell niche with increased neurogenesis [98-101,18,102,103], others show that expansion of the niche vasculature not necessarily is accompanied by augment in neurogenesis [98].

Demonstrating the functional significance of endothelial cells in the neural stem cell niche, Otonne and colleagues have demonstrated functional contact mediated cross-talk between endothelial cells and neural stem cells in vivo [104]. Conditional deletion of the transmembrane ligands, Jagged1 or ephrinB2, specifically in endothelial cells in vivo culminates in an expansion of proliferating neural stem cells, followed by their long-term depletion [104], indicating that these molecules are crucial to keep a reserve of neural stem cells in a quiescent state.

In the search for endothelially-secreted factors that regulate neural stem cells behavior, a recent study by Sato et al. (2017) revealed that soluble amyloid precursor protein derived from endothelial cells is essential for neural stem cell quiescence [105,106]. The authors found by in vitro experiments that soluble amyloid precursor protein suppresses neural stem cell growth, and enhances neurosphere-forming capacity, while maintaining their multipotency. Moreover, Sato and colleagues also discovered that, in amyloid precursor protein-null mice, there is a rise in neural stem cells proliferation in their niche [105]. Furthermore, using Tie2-Cre/amyloid precursor protein floxed mice, the authors deleted amyloid precursor protein specifically in endothelial cells, revealing that endothelial cells, but not astrocytes regulate neural stem cells activation in the subventricular zone through amyloid precursor protein [105]. As Tie 2 expression is not exclusive to endothelial cells $[107,108]$, it is possible that the observed neural stem cell response may be due to hematopoietic cells in which amyloid precursor protein was also genetically eliminated as well in Tie2-Cre/amyloid precursor protein floxed mice. To avoid Cre recombinase activity in hematopoietic cells, more specific mouse models should be used in future studies, such as VE-Cadherin-CreERT2 mice [109]. In VE-Cadherin-CreERT2/amyloid precursor protein floxed is possible control amyloid precursor protein expression in the endothelium at different stages.

The perivascular niches are themself complex and heterogeneous composed by multiple other cell types in addition to endothelial cells in the neurogenic niches, such as perivascular astrocytes, perivascular neurons [106,110,111], perivascular macrophages [112-114], perivascular adventitial cells [115], perivascular fibroblasts [116], microglia [117], vascular smooth muscle cells [118], and pericytes subsets [119]. Interestingly, pericytes from several peripheral tissues have been shown to behave as stem cells $[78,120-139,189,190]$, generating other cell types, and also to regulate the behavior of other stem cells, as hematopoietic stem cells in their niches [87,88,140-144]. Although growing evidence also shows that central nervous system pericytes alter their characteristics following stimuli and 
develop sternness [145-149], whether pericytes are an essential component of neural stem cell niche, and what are their exact roles remains unexplored. Future studies should elucidate what is the relationship between different components of the perivascular neural stem cell microenvironment. Is there a cross-talk between the different perivascular constituents of the neural stem cell niche? Also, the identification of molecules contributing to the anchoring of neural stem cells to the perivascular niche deserves further research.

\section{Neuronal role in the neural stem cell niche}

Neurotransmission has been classically defined as signaling between neuronal subtypes. Nevertheless, this concept has changed, and now we know that released neurotransmitters can signal not only to neurons, but also to other cell types present in the microenvironment where they are released. Recent studies have revealed that innervations are essential components of the neural stem cell niche, and the release of neurotransmitters affects the neural stem cell behavior in the neurogenic area [150]. Different from embryonic neurogenesis, adult neurogenesis is regulated also by neuronal activity [3,33,151-154]. Understanding which are the specific neurons that regulate neural stem cells in the adult brain and the underlying mechanisms is fundamental yet challenging. Mostly due to the lack until recently of techniques to access the behavior of neural stem cells in vivo. The recent technical advancements, such as characterization of specific neural stem cell markers, DREADDs (designer receptors exclusively activated by designer drugs), optogenetics, crosssynaptic specific tracing, and the evolution of Cre/loxp systems are bringing exciting findings and novel concepts to the field. Now researchers are in a unique position to answer essential questions about neuronal activity-dependent neural stem cell regulation.

Using the combination of lineage-tracing and optogenetics, Song and colleagues have recently revealed that dentate parvalbumin + interneurons regulate adult hippocampal neural stem cells via tonic GABA signaling in an activity-dependent manner [155,156]. Decrease in the activity of these interneurons promotes increase in the number of quiescent neural stem cells, while conversely activation of parvalbumin + interneurons inhibits the activation of neural stem cells $[152,155]$. Interneurons expressing neuropeptide $Y$ have been implicated in the control of adult neurogenesis via promoting neural stem cell proliferation [157-159]. Moreover, interneurons expressing vasoactive intestinal peptide (VIP) have been shown to mediate neurogenesis via VIP receptors on neural stem cells [160]. As hippocampal interneurons receive afferent inputs from distant brain regions, there is a need to understand how distal neuronal inputs impact adult hippocampal neural stem cells via local interneurons. One recent study by Bao and colleagues (2017) addressed this by using stateof-art techniques [161]. The authors discovered by using virus-based retrograde tracing that medial septum GABAergic neurons are the main afferents to the hippocampal parvalbumin + interneurons [161]. Markedly, GABA signaling derived from medial septum GABAergic neurons onto hippocampal parvalbumin + interneurons leads to neural stem cell regulation [161]. Depletion of medial septum GABAergic neurons results in neural stem cell depletion in the hippocampus, indicating that distal brain activity regulates hippocampal neural stem cell behavior [161]. Detailed characterization of multiple synaptic inputs that end onto distinct cellular components of the hippocampal neural stem cell niche will provide insights 
into the spatial organization of the local circuitry, and how it affects neural stem cell niche constituents.

The subventricular zone is also innervated by multiple nerve fibers of different origins that may influence the neural stem cell behavior. Neurons expressing nitric oxide synthase regulate neural stem cell proliferation by nitric oxide production [162]. The subventricular zone is also supplied by choline acetyltransferase expressing axons which regulate neural stem cell proliferation through the neurotransmitters that they produce $[163,164]$.

Additionally, selective lesion of dopaminergic nerve fibers leads to reduced proliferation of neural stem cells in the suventricular zone [165-168]. In a recent article in Journal of Neuroscience, Perez-Villalba and colleagues revealed an important component of the subventricular zone neural stem cell niche: a-synuclein possibly derived from dopaminergic axons maintains neural stem cells in their subventricular niche [169] (Fig. 4). The authors identified that $a$-synuclein is expressed in dopaminergic nerve fibers innervating the subventricular zone, but is not present in the suventricular zone itself. Perez-Villalba and colleagues discovered that the absence of a-synuclein, in a-synuclein knockout mice, leads to reduction in neural stem cells in the subventricular zone. Strikingly, adenovirus-mediated expression of a-synuclein in the substancia nigra neurons and L-DOPA treatment prevent neural stem cell loss in the neurogenic area [169]. This study brings strong evidence for the participation of dopaminergic in the maintenance of adult neural stem cells. Nevertheless, further studies need to confirm the participation of a-synuclein derived from dopaminergic fibers in the neural stem cell niche. The use of conventional knockout mice has proved to be a valuable tool for understanding the role of key proteins in physiological and pathological states. Nonetheless, these technologies produce broad changes in gene function throughout the body, affecting multiple different cells. Thus, they are limited in that they do little to identify the specific roles of a gene in a specific cell type. Because the molecular functions of a-synuclein may depend on a specific neuronal subpopulation in which it is expressed, restricting gene manipulation to specific neurons in the brain may be more useful for understanding the role of a-synuclein in the neural stem cell niche. Thus, conditional gene manipulation approaches provide an effective option. The main findings from this study are based on the data obtained from a-synuclein knockout mice. As during development asynuclein may be expressed in distinct tissues in various cellular populations [170], it is possible that the effect on neural stem cells could be due to other cell types in which asynuclein was deleted as well in the a-synuclein knockout mouse model. Because of this, the combination of mouse models that allow to target specifically dopaminergic neurons, such as tyrosine hydroxylase-Cre, with a-synuclein floxed mice will provide a tool to study the role of a-synuclein specifically within dopaminergic neurons.

Interestingly, recently, in Science, Paul and colleagues demonstrated that a subpopulation of hypothalamic nerve fibers essential in the control of hunger and satiety regulate adult neural stem cells proliferation in vivo $[171,172]$. The authors identified by in vitro assays aendorphin, an endogenous kappa opioid receptor ligand, as an extrinsic cue that activate quiescent neural stem cells. Furthermore, as $\beta$-endorphin is a posttranslational cleavage product of proopiomelanocortin [173], Paul and colleagues examined the function of proopiomelanocortin-expressing neurons in the neural stem cell microenvironment. Using state-of-the-art techniques including sophisticated in vivo inducible genetic approaches, such 
as lineage-tracing Cre/loxP mediated technologies in combination with viral vectors, the authors increased acutely proopiomelanocortin-expressing neurons activity using activating DREADDs (Designer Receptors Exclusively Activated by Designer Drugs) or selectively eliminated these neurons. These experiments revealed that proopiomelanocortin-expressing neurons affect neural stem cell proliferation in the anterior ventral subventricular zone [171,172]. Importantly, Paul and colleagues analyzed and manipulated hypothalamic neural activity in mice fed ad libitum or fasted, indicating that hunger and satiety states specifically regulate neural stem cells proliferation in the anterior ventral subventricular zone through proopiomelanocortin-expressing axons. This new study reveals a new constituent of the neural stem cell niche and shows that distal brain activity may regulate subventricular zone neural stem cell behavior.

\section{Clinical relevance}

Rodent models aim to recreate features of human physiology as closely as possible. Nevertheless, whether the same phenomena that is observed in mouse models occur in humans needs to be questioned. Also, whether there is conservation in the cellular and molecular mechanisms of regulation of neural stem cells in humans and mice remains poorly explored.

Nearly all our understanding of the neural stem cell behavior derives from studies in rodent models, and our knowledge about neural stem cells in the human brain is still very limited. Comparative analyzes of adult neurogenesis have uncovered a big variety in this phenomenon among different species [174]. Neuroanatomical experiments and modern techniques, such as radiocarbon dating, have proved that neural stem cells are present in the adult human brain [175]. The subventricular zone neurogenic niche differs between mice and humans, based on the cell types that form this area [176]. Newly formed neural progenitors in this zone also differ in their fate, becoming medium spiny neurons in the striatum [177], instead of forming olfactory interneurons as in mice [178]. Recent also have also shown that neural stem cells are present in the hypothalamic neurogenic region in the human adult brain $[179,180]$.

Although some studies have suggested that hippocampal neural stem cell niche in humans resembles the one in rodents, and the fate of neural stem cells are dentate granule neurons in both species [181,182], a recent intriguing study in Nature has challenged this concept [183]. Sorrells and colleagues found that the number of hippocampal neural stem cells and young neurons decreases in the first one year of age, and only few isolated young neurons are present in the hippocampus in the first decade of life [183]. Strikingly, the authors did not detect any neural stem cells or young neurons in the adult human dentate gyrus [183]. Additionally, Sorrells and colleagues assessed autopsies hippocampi from monkeys. Although the authors detected neurogenesis in the early postnatal life, it diminished with aging [183] (Fig. 5). In contrast, another study published in Cell Stem Cell at the same time suggested just the opposite [184]. Boldrini and colleagues analyzed the hippocampi of healthy humans of different ages. The authors revealed that neurogenesis in healthy older individuals without any neurological dysfunction was preserved with aging [184] (Fig. 6). The discrepancies between these two studies may be due to several technical issues, such as 
limitations of specific neural stem cell markers and quantitative aspects in humans, as it was elegantly discussed in a recent mini-review [185]. Very little is known about the niches of the neural stem cells in the distinct adult human brain neurogenic areas.

\section{Conclusions and perspectives}

The works discussed in this review illustrate the complexity of the microenvironments where neural stem cells are located in the brain. Multiple cell populations contribute to the complex maintenance and regulation of neural stem cells. The availability of refined genetic technologies has demonstrated that changes to the niche content may have profound effects on neural stem cell behavior. Recombination-based technologies provide powerful ways to interrogate the cellular and molecular components of the neural stem cell niches. Future clarification of the interactions between neural stem cells and their microenvironments in pathological conditions may lead to improved methods to exploit the clinical potential of neural stem cells. In the future, targeting the niche itself could become an attractive potential alternative for the treatment of neurological illnesses. The balance of extrinsic effects from the neurogenic niche can also differ under distinct physiological circumstances. Whether newborn, adult, and aged neural stem cells have variable physiological demands remains poorly understood. The examination of how the neural stem cells niches age will reveal essential information for the treatment of age-related neurological disorders. The biggest challenge for the future still will be to translate animal research into humans. Enhancing the availability of human brain tissue samples will be fundamental to reach this aim. There is also a need for novel strategies to study the generation of new neurons in vivo in the adult human brain. A more detailed analysis of single cell phenotypes in the neurogenic niches, by for instance single-neural stem cell RNA sequencing as well as by single-cell RNA sequencing of each of the neural stem cell niche components in the adult brain, will provide beneficial knowledge. Immense progress has been made in our understanding of the importance and the complexity of the niche to the function of neural stem cells and to the physiology of the organism as a whole. Nevertheless, the best is yet to come.

\section{Acknowledgments}

Alexander Birbrair is supported by a grant from Instituto Serrapilheira/Serra-1708-15285, a grant from Pro-reitoria de Pesquisa/Universidade Federal de Minas Gerais (PRPq/UFMG) (Edital 05/2016), a grant from National Institute of Science and Technology in Theranostics and Nanobiotechnology (CNPq/CAPES/FAPEMIG, Process No. 465669/2014-0), a grant from FAPEMIG [Rede Mineira de Engenharia de Tecidos e Terapia Celular (REMETTEC, RED-00570-16)], and a grant from FAPEMIG [Rede De Pesquisa Em Doengas Infecciosas Humanas E Animais Do Estado De Minas Gerais (RED-00313-16)]; Akiva Mintz is supported by the National Institute of Health (1R01CA179072-01A1) and by the American Cancer Society Mentored Research Scholar grant (124443MRSG-13-121-01-CDD).

\section{Abbreviations:}

$3 \mathbf{V}$

ARC

CD133 third ventricle

arcuate nucleus

cluster of differentiation 133, also known as prominin-1 


\begin{tabular}{|c|c|}
\hline CD15 & $\begin{array}{l}\text { cluster of differentiation } 15 \text {, also known as } 3 \text {-fucosyl- } N \text { - } \\
\text { acetyl-lactosamine }\end{array}$ \\
\hline CD24 & $\begin{array}{l}\text { cluster of differentiation 24, also known as Heat Stable } \\
\text { Antigen }\end{array}$ \\
\hline CD81 & $\begin{array}{l}\text { cluster of differentiation } 81 \text {, also known as target of the } \\
\text { antiproliferative antibody } 1 \text { and tetraspanin- } 28\end{array}$ \\
\hline CD9 & $\begin{array}{l}\text { cluster of differentiation } 9 \text {, also known as the motility } \\
\text { related protein-1 }\end{array}$ \\
\hline Cre & recombinase \\
\hline CreER & recombinase binded to estrogen receptor \\
\hline CSF & cerebrospinal fluid \\
\hline DCX & doublecortin \\
\hline DG & dentate gyrus \\
\hline DMH & dorsomedial hypothalamic \\
\hline DREADDs & $\begin{array}{l}\text { Designer Receptors Exclusively Activated by Designer } \\
\text { Drugs }\end{array}$ \\
\hline EGFR & Epidermal growth factor receptor \\
\hline ERT2 & mutated ligand-binding domain of the estrogen receptor \\
\hline FGF-2 & fibroblast growth factor type 2 \\
\hline GABA & gamma-aminobutyric acid \\
\hline GABAergic & pertaining to or affecting the neurotransmitter GABA \\
\hline GCL & granule cell layer \\
\hline GFAP & glial fibrillary acidic protein \\
\hline Glast & glutamate aspartate transporter \\
\hline Gli1 & $\begin{array}{l}\text { GLI-, Kruppel family member } 1 \text {, also known as glioma- } \\
\text { associated oncogene }\end{array}$ \\
\hline IGF-1 & Insulin-Like Growth Factor 1 \\
\hline L-DOPA & L-3,4-dihydroxyphenylalanine, also known as levodopa \\
\hline LHA & lateral hypothalamic area \\
\hline LoxP & locus of $\mathrm{X}$-over P1 \\
\hline ME & median eminence \\
\hline
\end{tabular}




\begin{tabular}{|c|c|}
\hline Mfge8 & $\begin{array}{l}\text { milk fat globule-epidermal growth factor, also known } \\
\text { aslactadherin or SED1 }\end{array}$ \\
\hline mRNA & messenger ribonucleic acid \\
\hline mTOR1 & mammalian target of rapamycin 1 \\
\hline NeuN & neuronal nuclear antigen \\
\hline NG2 & neuron-glial antigen 2, also known as CSPG4 \\
\hline NSC & neural stem cell \\
\hline PSA-NCAM & Polysialylated neural cell adhesion molecule \\
\hline PVH & paraventricular nucleus \\
\hline RGLs & radial glia like neural stem cells \\
\hline RNA & ribonucleic acid \\
\hline RNAseq & ribonucleic acid sequencing \\
\hline SGZ & subgranular zone \\
\hline SGZ & subgranular zone \\
\hline Sox1 & SRY-related HMG-box gene 1 \\
\hline SVZ & subventricular zone \\
\hline Tie2 & $\begin{array}{l}\text { tyrosine kinase with immunoglobulin-like and EGF-like } \\
\text { domains } 2\end{array}$ \\
\hline VE-Cadherin & vascular endothelial cadherin \\
\hline VEGF & vascular endothelial growth factor \\
\hline VIP & vasoactive intestinal peptide \\
\hline VMH & ventromedial hypothalamic \\
\hline Wnt & wingless/integrated \\
\hline a-SYN & a-synuclein \\
\hline
\end{tabular}

\section{References}

[1]. Truman JW, Developmental neuroethology of insect metamorphosis, J. Neurobiol. 23 (10) (1992) 1404-1422. [PubMed: 1487742]

[2]. Alvarez-Buylla A, Kirn JR, Nottebohm F, Birth of projection neurons in adult avian brain may be related to perceptual or motor learning, Science 249 (4975) (1990) 1444-1446. [PubMed: 1698312]

[3]. Kriegstein A, Alvarez-Buylla A, The glial nature of embryonic and adult neural stem cells, Annu. Rev. Neurosci. 32 (2009) 149-184. [PubMed: 19555289]

Semin Cell Dev Biol. Author manuscript; available in PMC 2019 December 07. 
[4]. Reynolds BA, Weiss S, Generation of neurons and astrocytes from isolated cells of the adult mammalian central nervous system, Science 255 (5052) (1992) 1707-1710. [PubMed: 1553558]

[5]. Li L, Clevers H, Coexistence of quiescent and active adult stem cells in mammals, Science 327 (5965) (2010) 542-545. [PubMed: 20110496]

[6]. Naik PP, Birbrair A, Bhutia SK, Mitophagy-driven metabolic switch reprograms stem cell fate, Cell. Mol. Life Sci.: CMLS (2018).

[7]. Arvidsson A, Collin T, Kirik D, Kokaia Z, Lindvall O, Neuronal replacement from endogenous precursors in the adult brain after stroke, Nat. Med. 8 (9) (2002) 963-970. [PubMed: 12161747]

[8]. Lin R, Iacovitti L, Classic and novel stem cell niches in brain homeostasis and repair, Brain Res. 1628 (Pt B) (2015) 327-342. [PubMed: 25931262]

[9]. Kokoeva MV, Yin H, Flier JS, Evidence for constitutive neural cell proliferation in the adult murine hypothalamus, J. Comp. Neurol. 505 (2) (2007) 209-220. [PubMed: 17853440]

[10]. Pierce AA, Xu AW, De novo neurogenesis in adult hypothalamus as a com $\neg$ pensatory mechanism to regulate energy balance, J. Nurosci. 30 (2) (2010) 723-730.

[11]. McNay DE, Briancon N, Kokoeva MV, Maratos-Flier E, Flier JS, Remodeling of the arcuate nucleus energy-balance circuit is inhibited in obese mice, J. Clin. Invest. 122 (1) (2012) 142-152. [PubMed: 22201680]

[12]. Calzolari F, Michel J, Baumgart EV, Theis F, Gotz M, Ninkovic J, Fast clonal expansion and limited neural stem cell self-renewal in the adult subependymal zone, Nat. Neurosci. 18 (4) (2015) 490-492. [PubMed: 25730673]

[13]. Bond AM, Ming GL, Song H, Adult mammalian neural stem cells and neuro 7 genesis: five decades later, Cell Stem Cell 17 (4) (2015) 385-395. [PubMed: 26431181]

[14]. Ihrie RA, Alvarez-Buylla A, Lake-front property: a unique germinal niche by the lateral ventricles of the adult brain, Neuron 70 (4) (2011) 674-686. [PubMed: 21609824]

[15]. Seri B, Garcia-Verdugo JM, McEwen BS, Alvarez-Buylla A, Astrocytes give rise to new neurons in the adult mammalian hippocampus, J. Neurosci. 21 (18) (2001) 7153-7160. [PubMed: 11549726]

[16]. Gage FH, Temple S, Neural stem cells: generating and regenerating the brain, Neuron 80 (3) (2013) 588-601. [PubMed: 24183012]

[17]. Kempermann G, Kuhn HG, Gage FH, More hippocampal neurons in adult mice living in an enriched environment, Nature 386 (6624) (1997) 493-495. [PubMed: 9087407]

[18]. van Praag H, Shubert T, Zhao C, Gage FH, Exercise enhances learning and hippocampal neurogenesis in aged mice, J. Neurosci. 25 (38) (2005) 8680-8685. [PubMed: 16177036]

[19]. Drapeau E, Mayo W, Aurousseau C, Le Moal M, Piazza PV, Abrous DN, Spatial memory performances of aged rats in the water maze predict levels of hippocampal neurogenesis, Proc. Natl. Acad. Sci. U. S. A. 100 (24) (2003) 14385-14390. [PubMed: 14614143]

[20]. Alvarez-Buylla A, Herrera DG, Wichterle H, The subventricular zone: source of neuronal precursors for brain repair, Prog. Brain Res. 127 (2000) 1-11. [PubMed: 11142024]

[21]. Breton-Provencher V, Lemasson M, Peralta MR 3rd, Saghatelyan A, Interneurons produced in adulthood are required for the normal functioning of the olfactory bulb network and for the execution of selected olfactory behaviors, J. Neurosci. 29 (48) (2009) 15245-15257. [PubMed: 19955377]

[22]. Gheusi G, Cremer H, McLean H, Chazal G, Vincent JD, Lledo PM, Importance of newly generated neurons in the adult olfactory bulb for odor discrimination, Proc. Natl. Acad. Sci. U. S. A. 97 (4) (2000) 1823-1828. [PubMed: 10677540]

[23]. Bonaguidi MA, Wheeler MA, Shapiro JS, Stadel RP, Sun GJ, Ming GL, Song H, In vivo clonal analysis reveals self-renewing and multipotent adult neural stem cell characteristics, Cell 145 (7) (2011) 1142-1155. [PubMed: 21664664]

[24]. Mirzadeh Z, Merkle FT, Soriano-Navarro M, Garcia-Verdugo JM, Alvarez- Buylla A, Neural stem cells confer unique pinwheel architecture to the ventricular surface in neurogenic regions of the adult brain, Cell Stem Cell 3 (3) (2008) 265-278. [PubMed: 18786414]

[25]. Bottai D, Scesa G, Cigognini D, Adami R, Nicora E, Abrignani S, Di Giulio AM, Gorio A, Third trimester NG2-positive amniotic fluid cells are effective in improving repair in spinal cord injury, Exp. Neurol. 254 (2014) 121-133. [PubMed: 24485983] 
[26]. Andreotti JP, Paiva AE, Prazeres P, Guerra DAP, Silva WN, Vaz RS, Mintz A, Birbrair A, The role of natural killer cells in the uterine microenvironment during pregnancy, Cell. Mol. Immunol. (2018).

[27]. Azevedo PO, Paiva AE, Santos GSP, Lousado L, Andreotti JP, Sena IFG, Mintz A, Birbrair A, Cross-talk between lung cancer and bones results in neutrophils that promote tumor progression, Cancer Metastasis Rev. (2018).

[28]. Guerra DAP, Paiva AE, Sena IFG, Azevedo PO, Batista ML Jr., Mintz A, Birbrair A, Adipocytes role in the bone marrow niche, Cytomet. Part A: J. Int. Soc. Anal. Cytol. 93 (2) (2018) 167-171.

[29]. Paiva AE, Lousado L, Almeida VM, Andreotti JP, Santos GSP, Azevedo PO, Sena IFG, Prazeres P, Borges IT, Azevedo V, Mintz A, Birbrair A, Endothelial cells as precursors for osteoblasts in the metastatic prostate Cancer bone, Neoplasia 19 (11) (2017) 928-931. [PubMed: 28957694]

[30]. Lousado L, Prazeres P, Andreotti JP, Paiva AE, Azevedo PO, Santos GSP, Filev R, Mintz A, Birbrair A, Schwann cell precursors as a source for adrenal gland chromaffin cells, Cell Death Dis. 8 (10) (2017) e3072. [PubMed: 28981120]

[31]. Rodrigues ACZ, Messi ML, Wang ZM, Abba MC, Pereyra A, Birbrair A, Zhang T, O'Meara M, Kwan P, Lopez EIS, Willis MS, Mintz A, Files DC, Furdui C, Oppenheim RW, Delbono O, The sympathetic nervous system regulates skeletal muscle motor innervation and acetylcholine receptor stability, Acta Physiol. (2018) e13195.

[32]. Birbrair A, Stem cell microenvironments and beyond, Adv. Exp. Med. Biol. 1041 (2017) 1-3. [PubMed: 29204825]

[33]. Ming GL, Song H, Adult neurogenesis in the mammalian brain: significant answers and significant questions, Neuron 70 (4) (2011) 687-702. [PubMed: 21609825]

[34]. Decimo I, Bifari F, Krampera M, Fumagalli G, Neural stem cell niches in health and diseases, Curr. Pharm. Des. 18 (13) (2012) 1755-1783. [PubMed: 22394166]

[35]. Goritz C, Frisen J, Neural stem cells and neurogenesis in the adult, Cell Stem Cell 10 (6) (2012) 657-659. [PubMed: 22704503]

[36]. Merkle FT, Fuentealba LC, Sanders TA, Magno L, Kessaris N, Alvarez- Buylla A, Adult neural stem cells in distinct microdomains generate previously unknown interneuron types, Nat. Neurosci. 17 (2) (2014) 207-214. [PubMed: 24362763]

[37]. Fiorelli R, Azim K, Fischer B, Raineteau O, Adding a spatial dimension to postnatal ventricularsubventricular zone neurogenesis, Development 142 (12) (2015) 2109-2120. [PubMed: 26081572]

[38]. Fuentealba LC, Rompani SB, Parraguez JI, Obernier K, Romero R, Cepko CL, Alvarez-Buylla A, Embryonic origin of postnatal neural stem cells, Cell 161 (7) (2015) 1644-1655. [PubMed: 26091041]

[39]. Merkle FT, Mirzadeh Z, Alvarez-Buylla A, Mosaic organization of neural stem cells in the adult brain, Science 317 (5836) (2007) 381-384. [PubMed: 17615304]

[40]. Isomura A, Kageyama R, Ultradian oscillations and pulses: coordinating cellular responses and cell fate decisions, Development 141 (19) (2014) 3627-3636. [PubMed: 25249457]

[41]. Kohwi M, Doe CQ, Temporal fate specification and neural progenitor competence during development, Nature reviews, Neuroscience 14 (12) (2013) 823-838. [PubMed: 24400340]

[42]. Ramos AD, Andersen RE, Liu SJ, Nowakowski TJ, Hong SJ, Gertz C, Salinas RD, Zarabi H, Kriegstein AR, Lim DA, The long noncoding RNA Pnky regulates neuronal differentiation of embryonic and postnatal neural stem cells, Cell Stem Cell 16 (4) (2015) 439-447. [PubMed: 25800779]

[43]. Capela A, Temple S, LeX/ssea-1 is expressed by adult mouse CNS stem cells, identifying them as nonependymal, Neuron 35 (5) (2002) 865-875. [PubMed: 12372282]

[44]. Corti S, Nizzardo M, Nardini M, Donadoni C, Locatelli F, Papadimitriou D, Salani S, Del Bo R, Ghezzi S, Strazzer S, Bresolin N, Comi GP, Isolation and characterization of murine neural stem/ progenitor cells based on Prominin-1 expression, Exp. Neurol. 205 (2) (2007) 547-562. [PubMed: 17466977]

[45]. Barraud P, Thompson L, Kirik D, Bjorklund A, Parmar M, Isolation and characterization of neural precursor cells from the Sox1-GFP reporter mouse, Eur. J. Neurosci. 22 (7) (2005) 15551569. [PubMed: 16197496] 
[46]. Kawaguchi A, Miyata T, Sawamoto K, Takashita N, Murayama A, Akamatsu W, Ogawa M, Okabe M, Tano Y, Goldman SA, Okano H, Nestin-EGFP transgenic mice: visualization of the self-renewal and multipotency of CNS stem cells, Mol. Cell. Neurosci. 17 (2) (2001) 259-273. [PubMed: 11178865]

[47]. Birbrair A, Sattiraju A, Zhu D, Zulato G, Batista I, Nguyen VT, Messi ML, Solingapuram Sai KK, Marini FC, Delbono O, Mintz A, Novel peripherally derived neural-like stem cells as therapeutic carriers for treating glioblastomas, Stem Cells Transl. Med. 6 (2) (2017) 471-481. [PubMed: 28191774]

[48]. Birbrair A, Wang ZM, Messi ML, Enikolopov GN, Delbono O, Nestin-GFP transgene reveals neural precursor cells in adult skeletal muscle, PLoS One 6 (2) (2011) e16816.

[49]. Doetsch F, Petreanu L, Caille I, Garcia-Verdugo JM, Alvarez-Buylla A, EGF converts transitamplifying neurogenic precursors in the adult brain into multipotent stem cells, Neuron 36 (6) (2002) 1021-1034. [PubMed: 12495619]

[50]. Luo Y, Coskun V, Liang A, Yu J, Cheng L, Ge W, Shi Z, Zhang K, Li C, Cui Y, Lin H, Luo D, Wang J, Lin C, Dai Z, Zhu H, Zhang J, Liu J, Liu H, deVellis J, Horvath S, Sun YE, Li S, Singlecell transcriptome analyses reveal signals to activate dormant neural stem cells, Cell 161 (5) (2015) 1175-1186. [PubMed: 26000486]

[51]. Pastrana E, Cheng LC, Doetsch F, Simultaneous prospective purification of adult subventricular zone neural stem cells and their progeny, Proc. Natl. Acad. Sci. U. S. A. 106 (15) (2009) 63876392. [PubMed: 19332781]

[52]. Codega P, Silva-Vargas V, Paul A, Maldonado-Soto AR, Deleo AM, Pastrana E, Doetsch F, Prospective identification and purification of quiescent adult neural stem cells from their in vivo niche, Neuron 82 (3) (2014) 545-559. [PubMed: 24811379]

[53]. Llorens-Bobadilla E, Zhao S, Baser A, Saiz-Castro G, Zwadlo K, Martin-Villalba A, Single-cell transcriptomics reveals a population of dormant neural stem cells that become activated upon brain injury, Cell Stem Cell 17 (3) (2015) 329-340. [PubMed: 26235341]

[54]. Azim K, Zweifel S, Klaus F, Yoshikawa K, Amrein I, Raineteau O, Early decline in progenitor diversity in the marmoset lateral ventricle, Cereb. Cortex 23 (4) (2013) 922-931. [PubMed: 22473896]

[55]. DeCarolis NA, Mechanic M, Petrik D, Carlton A, Ables JL, Malhotra S, Bachoo R, Gotz M, Lagace DC, Eisch AJ, In vivo contribution of nestin-and GLAST-lineage cells to adult hippocampal neurogenesis, Hippocampus 23 (8) (2013) 708-719. [PubMed: 23554226]

[56]. Gebara E, Bonaguidi MA, Beckervordersandforth R, Sultan S, Udry F, Gijs PJ, Lie DC, Ming GL, Song H, Toni N, Heterogeneity of radial glia-like cells in the adult Hippocampus, Stem Cells 34 (4) (2016) 997-1010. [PubMed: 26729510]

[57]. Amaral DG, Witter MP, The three-dimensional organization of the hippocampal formation: a review of anatomical data, Neuroscience 31 (3) (1989) 571-591. [PubMed: 2687721]

[58]. Wu MV, Sahay A, Duman RS, Hen R, Functional differentiation of adult-born neurons along the septotemporal axis of the dentate gyrus, Cold Spring Harb. Perspect. Biol. 7 (8) (2015) a018978.

[59]. Sun J, Bonaguidi MA, Jun H, Guo JU, Sun GJ, Will B, Yang Z, Jang MH, Song H, Ming GL, Christian KM, A septo-temporal molecular gradient of sfrp3 in the dentate gyrus differentially regulates quiescent adult hippocampal neural stem cell activation, Mol. Brain 8 (2015) 52. [PubMed: 26337530]

[60]. Jang MH, Bonaguidi MA, Kitabatake Y, Sun J, Song J, Kang E, Jun H, Zhong C, Su Y, Guo JU, Wang MX, Sailor KA, Kim JY, Gao Y, Christian KM, Ming GL, Song H, Secreted frizzledrelated protein 3 regulates activity-dependent adult hippocampal neurogenesis, Cell Stem Cell 12 (2) (2013) 215-223. [PubMed: 23395446]

[61]. Piatti VC, Davies-Sala MG, Esposito MS, Mongiat LA, Trinchero MF, Schinder AF, The timing for neuronal maturation in the adult hippocampus is modulated by local network activity, J. Neurosci. 31 (21) (2011) 7715-7728. [PubMed: 21613484]

[62]. Jinno S, Topographic differences in adult neurogenesis in the mouse hippocampus: a stereologybased study using endogenous markers, Hippocampus 21 (5) (2011) 467-480. [PubMed: 20087889] 
[63]. Ninkovic J, Gotz M, How to make neurons-thoughts on the molecular logic of neurogenesis in the central nervous system, Cell Tissue Res. 359 (1) (2015) 5-16. [PubMed: 25416507]

[64]. Lehtinen MK, Bjornsson CS, Dymecki SM, Gilbertson RJ, Holtzman DM, Monuki ES, The choroid plexus and cerebrospinal fluid: emerging roles in development, disease, and therapy, J. Neurosci. 33 (45) (2013) 17553-9. [PubMed: 24198345]

[65]. Redzic ZB, Preston JE, Duncan JA, Chodobski A, Szmydynger-Chodobska J, The choroid plexus-cerebrospinal fluid system: from development to aging, Curr. Top. Dev. Biol. 71 (2005) 152. [PubMed: 16344101]

[66]. Johanson CE, Duncan JA 3rd, Klinge PM, Brinker T, Stopa EG, Silverberg GD, Multiplicity of cerebrospinal fluid functions: new challenges in health and disease, Cerebrospinal Fluid Res. 5 (2008) 10. [PubMed: 18479516]

[67]. Lehtinen MK, Zappaterra MW, Chen X, Yang YJ, Hill AD, Lun M, Maynard T, Gonzalez D, Kim S, Ye P, D'Ercole AJ, Wong ET, LaMantia AS, Walsh CA, The cerebrospinal fluid provides a proliferative niche for neural progenitor cells, Neuron 69 (5) (2011) 893-905. [PubMed: 21382550]

[68]. Silva-Vargas V, Maldonado-Soto AR, Mizrak D, Codega P, Doetsch F, Age-dependent niche signals from the choroid plexus regulate adult neural stem cells, Cell Stem Cell 19 (5) (2016) 643-652. [PubMed: 27452173]

[69]. Sawamoto K, Wichterle H, Gonzalez-Perez O, Cholfin JA, Yamada M, Spassky N, Murcia NS, Garcia-Verdugo JM, Marin O, Rubenstein JL, Tessier-Lavigne M, Okano H, Alvarez-Buylla A, New neurons follow the flow of cerebrospinal fluid in the adult brain, Science 311 (5761) (2006) 629-632. [PubMed: 16410488]

[70]. Johansson PA, Irmler M, Acampora D, Beckers J, Simeone A, Gotz M, The transcription factor Otx2 regulates choroid plexus development and function, Development 140 (5) (2013) 10551066. [PubMed: 23364326]

[71]. Johansson PA, Cappello S, Gotz M, Stem cells niches during development-les- sons from the cerebral cortex, Curr. Opin. Neurobiol. 20 (4) (2010) 400-407. [PubMed: 20447822]

[72]. Falcao AM, Marques F, Novais A, Sousa N, Palha JA, Sousa JC, The path from the choroid plexus to the subventricular zone: go with the flow!, Front. Cell. Neurosci. 6 (2012) 34. [PubMed: 22907990]

[73]. Stolp HB, Neuropoietic cytokines in normal brain development and neurodevelopmental disorders, Mol. Cell. Neurosci. 53 (2013) 63-68. [PubMed: 22926235]

[74]. Dziegielewska KM, Knott GW, Saunders NR, The nature and composition of the internal environment of the developing brain, Cell. Mol. Neurobiol. 20 (1) (2000) 41-56. [PubMed: 10690501]

[75]. Delgado AC, Ferron SR, Vicente D, Porlan E, Perez-Villalba A, Trujillo CM, D’Ocon P, Farinas I, Endothelial NT-3 delivered by vasculature and CSF promotes quiescence of subependymal neural stem cells through nitric oxide induction, Neuron 83 (3) (2014) 572-585. [PubMed: 25043422]

[76]. Zappaterra MW, Lehtinen MK, The cerebrospinal fluid: regulator of neurogenesis, behavior, and beyond, Cell. Mol. Life Sci.: CMLS 69 (17) (2012) 2863-2878. [PubMed: 22415326]

[77]. Petrik D, Myoga MH, Grade S, Gerkau NJ, Pusch M, Rose CR, Grothe B, Gotz M, Epithelial sodium channel regulates adult neural stem cell proliferation in a flow-dependent manner, Cell Stem Cell 22 (6) (2018) 865-878 e8. [PubMed: 29779889]

[78]. Birbrair A, Borges IDT, Gilson Sena IF, Almeida GG, da Silva Meirelles L, Goncalves R, Mintz A, Delbono O, How plastic are pericytes? Stem Cells Dev. 26 (14) (2017) 1013-1019. [PubMed: 28490256]

[79]. Dias DO, Kim H, Holl D, Werne Solnestam B, Lundeberg J, Carlen M, Goritz C, Frisen J, Reducing pericyte-derived scarring promotes recovery after spinal cord injury, Cell 173 (1) (2018) 153-165 e22. [PubMed: 29502968]

[80]. Zhou Y, Bond AM, Shade JE, Zhu Y, Davis CO, Wang X, Su Y, Yoon KJ, Phan AT, Chen WJ, Oh JH, Marsh-Armstrong N, Atabai K, Ming GL, Song H, Autocrine Mfge8 signaling prevents developmental exhaustion of the adult neural stem cell pool, Cell Stem Cell 23 (3) (2018) 444452 e4. [PubMed: 30174295] 
[81]. Shin J, Berg DA, Zhu Y, Shin JY, Song J, Bonaguidi MA, Enikolopov G, Nauen DW, Christian KM, Ming GL, Song H, Single-cell RNA-Seq with waterfall reveals molecular cascades underlying adult neurogenesis, Cell Stem Cell 17 (3) (2015) 360-372. [PubMed: 26299571]

[82]. Schneider RK, Mullally A, Dugourd A, Peisker F, Hoogenboezem R, Van Strien PMH, Bindels EM, Heckl D, Busche G, Fleck D, Muller-Newen G, Wongboonsin J, Ventura Ferreira M, Puelles VG, Saez-Rodriguez J, Ebert BL, Humphreys BD, Kramann R, Gli1+ mesenchymal stromal cells are a key driver of bone marrow fibrosis and an important cellular therapeutic target, Cell Stem Cell 20 (6) (2017) 785-800 e8. [PubMed: 28457748]

[83]. Sena IFG, Prazeres P, Santos GSP, Borges IT, Azevedo PO, Andreotti JP, Almeida VM, Paiva AE, Guerra DAP, Lousado L, Souto L, Mintz A, Birbrair A, Identity of Gli1+ cells in the bone marrow, Exp. Hematol. 54 (2017) 12-16. [PubMed: 28690072]

[84]. Sena IFG, Borges IT, Lousado L, Azevedo PO, Andreotti JP, Almeida VM, Paiva AE, Santos GSP, Guerra DAP, Prazeres P, Souto L, Mintz A, Birbrair A, LepR+ cells dispute hegemony with Gli1+ cells in bone marrow fibrosis, Cell Cycle (2017) 1-5.

[85]. Yoshida S, Sukeno M, Nabeshima Y, A vasculature-associated niche for undifferentiated spermatogonia in the mouse testis, Science 317 (5845) (2007) 1722-1726. [PubMed: 17823316]

[86]. Tang W, Zeve D, Suh JM, Bosnakovski D, Kyba M, Hammer RE, Tallquist MD, Graff JM, White fat progenitor cells reside in the adipose vasculature, Science 322 (5901) (2008) 583-586. [PubMed: 18801968]

[87]. Asada N, Kunisaki Y, Pierce H, Wang Z, Fernandez NF, Birbrair A, Ma'ayan A, Frenette PS, Differential cytokine contributions of perivascular haematopoietic stem cell niches, Nat. Cell Biol. 19 (3) (2017) 214-223. [PubMed: 28218906]

[88]. Khan JA, Mendelson A, Kunisaki Y, Birbrair A, Kou Y, Arnal-Estape A, Pinho S, Ciero P, Nakahara F, Ma'ayan A, Bergman A, Merad M, Frenette PS, Fetal liver hematopoietic stem cell niches associate with portal vessels, Science 351 (6269) (2016) 176-180. [PubMed: 26634440]

[89]. Palmer TD, Willhoite AR, Gage FH, Vascular niche for adult hippocampal neurogenesis, J. Comp. Neurol. 425 (4) (2000) 479-494. [PubMed: 10975875]

[90]. Shen Q, Wang Y, Kokovay E, Lin G, Chuang SM, Goderie SK, Roysam B, Temple S, Adult SVZ stem cells lie in a vascular niche: a quantitative analysis of niche cell-cell interactions, Cell Stem Cell 3 (3) (2008) 289-300. [PubMed: 18786416]

[91]. Tavazoie M, Van der Veken L, Silva-Vargas V, Louissaint M, Colonna L, Zaidi B, GarciaVerdugo JM, Doetsch F, A specialized vascular niche for adult neural stem cells, Cell Stem Cell 3 (3) (2008) 279-288. [PubMed: 18786415]

[92]. Culver JC, Vadakkan TJ, Dickinson ME, A specialized microvascular domain in the mouse neural stem cell niche, PLoS One 8 (1) (2013) e53546.

[93]. Kazanis I, Lathia JD, Vadakkan TJ, Raborn E, Wan R, Mughal MR, Eckley DM, Sasaki T, Patton B, Mattson MP, Hirschi KK, Dickinson ME, ffrench-Constant C, Quiescence and activation of stem and precursor cell populations in the subependymal zone of the mammalian brain are associated with distinct cellular and extracellular matrix signals, J. Neurosci. 30 (29) (2010) 9771-9781. [PubMed: 20660259]

[94]. Lacar B, Young SZ, Platel JC, Bordey A, Gap junction-mediated calcium waves define communication networks among murine postnatal neural progenitor cells, Eur. J. Neurosci. 34 (12) (2011) 1895-1905. [PubMed: 22098557]

[95]. Petrik D, Yun S, Latchney SE, Kamrudin S, LeBlanc JA, Bibb JA, Eisch AJ, Early postnatal in vivo gliogenesis from nestin-lineage progenitors requires cdk5, PLoS One 8 (8) (2013) e72819.

[96]. Mignone JL, Kukekov V, Chiang AS, Steindler D, Enikolopov G, Neural stem and progenitor cells in nestin-GFP transgenic mice, J. Comp. Neurol. 469 (3) (2004) 311-324. [PubMed: 14730584]

[97]. Kokovay E, Goderie S, Wang Y, Lotz S, Lin G, Sun Y, Roysam B, Shen Q, Temple S, Adult SVZ lineage cells home to and leave the vascular niche via differential responses to SDF1/CXCR4 signaling, Cell Stem Cell 7 (2) (2010) 163-173. [PubMed: 20682445]

[98]. Cao L, Jiao X, Zuzga DS, Liu Y, Fong DM, Young D, During MJ, VEGF links hippocampal activity with neurogenesis, learning and memory, Nat. Genet. 36 (8) (2004) 827-835. [PubMed: 15258583] 
[99]. Jin K, Zhu Y, Sun Y, Mao XO, Xie L, Greenberg DA, Vascular endothelial growth factor (VEGF) stimulates neurogenesis in vitro and in vivo, Proc. Natl. Acad. Sci. U. S. A. 99 (18) (2002) 11946-11950. [PubMed: 12181492]

[100]. Licht T, Goshen I, Avital A, Kreisel T, Zubedat S, Eavri R, Segal M, Yirmiya R, Keshet E, Reversible modulations of neuronal plasticity by VEGF, Proc. Natl. Acad. Sci. U. S. A. 108 (12) (2011) 5081-5086. [PubMed: 21385942]

[101]. Udo H, Yoshida Y, Kino T, Ohnuki K, Mizunoya W, Mukuda T, Sugiyama H, Enhanced adult neurogenesis and angiogenesis and altered affective behaviors in mice overexpressing vascular endothelial growth factor 120, J. Neurosci. 28 (53) (2008) 14522-14536. [PubMed: 19118187]

[102]. Pereira AC, Huddleston DE, Brickman AM, Sosunov AA, Hen R, McKhann GM, Sloan R, Gage FH, Brown TR, Small SA, An in vivo correlate of exercise-induced neurogenesis in the adult dentate gyrus, Proc. Natl. Acad. Sci. U. S. A. 104 (13) (2007) 5638-5643. [PubMed: 17374720]

[103]. Van der Borght K, Kobor-Nyakas DE, Klauke K, Eggen BJ, Nyakas C, Van der Zee EA, Meerlo $\mathrm{P}$, Physical exercise leads to rapid adaptations in hippocampal vasculature: temporal dynamics and relationship to cell proliferation and neurogenesis, Hippocampus 19 (10) (2009) 928-936. [PubMed: 19212941]

[104]. Ottone C, Krusche B, Whitby A, Clements M, Quadrato G, Pitulescu ME, Adams RH, Parrinello S, Direct cell-cell contact with the vascular niche main $\neg$ tains quiescent neural stem cells, Nat. Cell Biol. 16 (11) (2014) 1045-1056. [PubMed: 25283993]

[105]. Sato Y, Uchida Y, Hu J, Young-Pearse TL, Niikura T, Mukouyama YS, Soluble APP functions as a vascular niche signal that controls adult neural stem cell number, Development (2017).

[106]. Azevedo PO, Lousado L, Paiva AE, Andreotti JP, Santos GSP, Sena IFG, Prazeres P, Filev R, Mintz A, Birbrair A, Endothelial cells maintain neural stem cells quiescent in their niche, Neuroscience 363 (2017) 62-65. [PubMed: 28893649]

[107]. Arai F, Hirao A, Ohmura M, Sato H, Matsuoka S, Takubo K, Ito K, Koh GY, Suda T, Tie2/ angiopoietin-1 signaling regulates hematopoietic stem cell quiescence in the bone marrow niche, Cell 118 (2) (2004) 149-161. [PubMed: 15260986]

[108]. Takakura N, Huang XL, Naruse T, Hamaguchi I, Dumont DJ, Yancopoulos GD, Suda T, Critical role of the TIE2 endothelial cell receptor in the development of definitive hematopoiesis, Immunity 9 (5) (1998) 677-686. [PubMed: 9846489]

[109]. Park DY, Lee J, Kim J, Kim K, Hong S, Han S, Kubota Y, Augustin HG, Ding L, Kim JW, Kim H, He Y, Adams RH, Koh GY, Plastic roles of pericytes in the blood-retinal barrier, Nat. Commun. 8 (2017) 15296. [PubMed: 28508859]

[110]. Mishra A, Reynolds JP, Chen Y, Gourine AV, Rusakov DA, Attwell D, Astrocytes mediate neurovascular signaling to capillary pericytes but not to arterioles, Nat. Neurosci. 19 (12) (2016) 1619-1627. [PubMed: 27775719]

[111]. Kisler K, Nelson AR, Montagne A, Zlokovic BV, Cerebral blood flow regulation and neurovascular dysfunction in Alzheimer disease, Nat. Rev. Neurosci. 18 (7) (2017) 419-434. [PubMed: 28515434]

[112]. Bechmann I, Priller J, Kovac A, Bontert M, Wehner T, Klett FF, Bohsung J, Stuschke M, Dirnagl U, Nitsch R, Immune surveillance of mouse brain perivascular spaces by blood-borne macrophages, Eur. J. Neurosci. 14 (10) (2001) 1651-1658. [PubMed: 11860459]

[113]. Silva WN, Prazeres P, Paiva AE, Lousado L, Turquetti AOM, Barreto RSN, de Alvarenga EC, Miglino MA, Goncalves R, Mintz A, Birbrair A, Macrophage- derived GPNMB accelerates skin healing, Exp. Dermatol. (2018).

[114]. Prazeres P, Almeida VM, Lousado L, Andreotti JP, Paiva AE, Santos GSP, Azevedo PO, Souto L, Almeida GG, Filev R, Mintz A, Goncalves R, Birbrair A, Macrophages generate pericytes in the developing brain, Cell. Mol. Neurobiol. 38 (4) (2018) 777-782. [PubMed: 28894964]

[115]. Crisan M, Corselli M, Chen WC, Peault B, Perivascular cells for regenerative medicine, J. Cell. Mol. Med. (2012).

[116]. Soderblom C, Luo X, Blumenthal E, Bray E, Lyapichev K, Ramos J, Krishnan V, Lai-Hsu C, Park KK, Tsoulfas P, Lee JK, Perivascular fibroblasts form the fibrotic scar after contusive spinal cord injury, J. Neurosci. 33 (34) (2013) 13882-13887. [PubMed: 23966707] 
[117]. Guillemin GJ, Brew BJ, Microglia, macrophages, perivascular macrophages, and pericytes: a review of function and identification, J. Leukoc. Biol. 75 (3) (2004) 388-397. [PubMed: 14612429]

[118]. Wanjare M, Kusuma S, Gerecht S, Perivascular cells in blood vessel regeneration, Biotechnol. J. 8 (4) (2013) 434-447. [PubMed: 23554249]

[119]. Birbrair A, Zhang T, Wang ZM, Messi ML, Olson JD, Mintz A, Delbono O, Type-2 pericytes participate in normal and tumoral angiogenesis, Am. J. Physiol. Cell Physiol. 307 (1) (2014) C25-38. [PubMed: 24788248]

[120]. Santos GSP, Magno LAV, Romano-Silva MA, Mintz A, Birbrair A, Pericytes plasticity in the brain, Neurosci. Bull. (2018).

[121]. Almeida VM, Paiva AE, Sena IFG, Mintz A, Magno LAV, Birbrair A, Pericytes make spinal cord breathless after injury, Neuroscientist (2017).

[122]. Silva WN, Leonel C, Prazeres P, Sena IFG, Guerra DAP, Heller D, Diniz IMA, Fortuna V, Mintz A, Birbrair A, Role of Schwann cells in cutaneous wound healing, Wound Repair Regen. (2018).

[123]. Prazeres PHDM, Turquetti AOM, Azevedo PO, Barreto RSN, Miglino MA, Mintz A, Delbono $\mathrm{O}$, Birbrair A, Perivascular cell av integrins as a target to treat skeletal muscle fibrosis, Int. J. Biochem. Cell Biol. (2018).

[124]. Guerra DAP, Paiva AE, Sena IFG, Azevedo PO, Silva WN, Mintz A, Birbrair A, Targeting glioblastoma-derived pericytes improves chemotherapeutic outcome, Angiogenesis (2018).

[125]. Sena IFG, Paiva AE, Prazeres P, Azevedo PO, Lousado L, Bhutia SK, Salmina AB, Mintz A, Birbrair A, Glioblastoma-activated pericytes support tumor growth via immunosuppression, Cancer Med. (2018).

[126]. Santos GSP, Prazeres P, Mintz A, Birbrair A, Role of pericytes in the retina, Eye (2017).

[127]. Costa MA, Paiva AE, Andreotti JP, Cardoso MV, Cardoso CD, Mintz A, Birbrair A, Pericytes constrict blood vessels after myocardial ischemia, J. Mol. Cell. Cardiol. (2018).

[128]. Coatti GC, Frangini M, Valadares MC, Gomes JP, Lima NO, Cavacana N, Assoni AF, Pelatti MV, Birbrair A, de Lima ACP, Singer JM, Rocha FMM, Da Silva GL, Mantovani MS, MacedoSouza LI, Ferrari MFR, Zatz M, Pericytes extend survival of ALS SOD1 mice and induce the expression of antioxidant enzymes in the murine model and in IPSCs derived neuronal cells from an ALS patient, Stem Cell Rev. (2017).

[129]. Dias Moura Prazeres PH, Sena IFG, Borges IDT, de Azevedo PO, Andreotti JP, de Paiva AE, de Almeida VM, de Paula Guerra DA, Pinheiro Dos Santos GS, Mintz A, Delbono O, Birbrair A, Pericytes are heterogeneous in their origin within the same tissue, Dev. Biol. 427 (1) (2017) 611. [PubMed: 28479340]

[130]. Birbrair A, Pericyte biology: development, Homeostasis Dis. Adv. Exp. Med. Biol. (2018).

[131]. Birbrair A, Prazeres PHDM, Files DC, Delbono O, Pericytes and t cells in lung injury and fibroproliferation, Molecular and Translational Medicine book series Fibrosis in Disease, (2019).

[132]. Birbrair A, Delbono O, Pericytes are essential for skeletal muscle formation, Stem Cell Rev. 11 (4) (2015) 547-548.

[133]. Birbrair A, Zhang T, Wang ZM, Messi ML, Mintz A, Delbono O, Pericytes at the intersection between tissue regeneration and pathology, Clin. Sci. 128 (2) (2015) 81-93. [PubMed: 25236972]

[134]. Birbrair A, Zhang T, Files DC, Mannava S, Smith T, Wang ZM, Messi ML, Mintz A, Delbono O, Type-1 pericytes accumulate after tissue injury and produce collagen in an organ-dependent manner, Stem Cell Res. Ther. 5 (6) (2014) 122. [PubMed: 25376879]

[135]. Birbrair A, Zhang T, Wang ZM, Messi ML, Mintz A, Delbono O, Pericytes: multitasking cells in the regeneration of injured, diseased, and aged skeletal muscle, Front. Aging Neurosci. 6 (2014) 245. [PubMed: 25278877]

[136]. Birbrair A, Zhang T, Wang ZM, Messi ML, Mintz A, Delbono O, Type-1 pericytes participate in fibrous tissue deposition in aged skeletal muscle, Am. J. Physiol. Cell Physiol. 305 (11) (2013) C1098-113. [PubMed: 24067916]

[137]. Birbrair A, Zhang T, Wang ZM, Messi ML, Enikolopov GN, Mintz A, Delbono O, Role of pericytes in skeletal muscle regeneration and fat accumulation, Stem Cells Dev. 22 (16) (2013) 2298-2314. [PubMed: 23517218] 
[138]. Birbrair A, Zhang T, Wang ZM, Messi ML, Enikolopov GN, Mintz A, Delbono O, Skeletal muscle neural progenitor cells exhibit properties of NG2-glia, Exp. Cell Res. 319 (1) (2013) 4563. [PubMed: 22999866]

[139]. Birbrair A, Zhang T, Wang ZM, Messi ML, Enikolopov GN, Mintz A, Delbono O, Skeletal muscle pericyte subtypes differ in their differentiation potential, Stem Cell Res. 10 (1) (2013) 6784. [PubMed: 23128780]

[140]. Azevedo PO, Sena IFG, Andreotti JP, Carvalho-Tavares J, Alves-Filho JC, Cunha TM, Cunha FQ, Mintz A, Birbrair A, Pericytes modulate myelination in the central nervous system, J. Cell. Physiol. (2017).

[141]. Borges I, Sena I, Azevedo P, Andreotti J, Almeida V, Paiva A, Santos G, Guerra D, Prazeres P, Mesquita LL, Silva LSB, Leonel C, Mintz A, Birbrair A, Lung as a niche for hematopoietic progenitors, Stem Cell Rev. 13 (5) (2017) 567-574.

[142]. Alvarenga EC, Silva WN, Vasconcellos R, Paredes-Gamero EJ, Mintz A, Birbrair A, Promyelocytic leukemia protein in mesenchymal stem cells is essential for leukemia progression, Ann. Hematol. (2018).

[143]. Paiva AE, Lousado L, Guerra DAP, Azevedo PO, Sena IFG, Andreotti JP, Santos GSP, Goncalves R, Mintz A, Birbrair A, Pericytes in the premetastatic niche, Cancer Res. (2018).

[144]. Birbrair A, Frenette PS, Niche heterogeneity in the bone marrow, Ann. N. Y. Acad. Sci. 1370 (1) (2016) 82-96. [PubMed: 27015419]

[145]. Sakuma R, Kawahara M, Nakano-Doi A, Takahashi A, Tanaka Y, Narita A, Kuwahara-Otani S, Hayakawa T, Yagi H, Matsuyama T, Nakagomi T, Brain pericytes serve as microglia-generating multipotent vascular stem cells following ischemic stroke, J. Neuroinflamm. 13 (1) (2016) 57.

[146]. Gouveia A, Seegobin M, Kannangara TS, He L, Wondisford F, Comin CH, Costa LDF, Beique JC, Lagace DC, Lacoste B, Wang J, The aPKC-CBP pathway regulates post-stroke neurovascular remodeling and functional recovery, Stem Cell Rep. 9 (6) (2017) 1735-1744.

[147]. Nakagomi T, Kubo S, Nakano-Doi A, Sakuma R, Lu S, Narita A, Kawahara M, Taguchi A, Matsuyama T, Brain vascular pericytes following ischemia have multipotential stem cell activity to differentiate into neural and vascular lineage cells, Stem Cells 33 (6) (2015) 1962-1974. [PubMed: 25694098]

[148]. Takagi T, Yoshimura S, Sakuma R, Nakano-Doi A, Matsuyama T, Nakagomi T, Novel regenerative therapies based on regionally induced multipotent stem cells in post-stroke brains: their origin, characterization, and perspective, Transl. Stroke Res. 8 (6) (2017) 515-528. [PubMed: 28744717]

[149]. Tatebayashi K, Tanaka Y, Nakano-Doi A, Sakuma R, Kamachi S, Shirakawa M, Uchida K, Kageyama H, Takagi T, Yoshimura S, Matsuyama T, Nakagomi T, Identification of multipotent stem cells in human brain tissue following stroke, Stem Cells Dev. 26 (11) (2017) 787-797. [PubMed: 28323540]

[150]. Bjornsson CS, Apostolopoulou M, Tian Y, Temple S, It takes a village: constructing the neurogenic niche, Dev. Cell 32 (4) (2015) 435-446. [PubMed: 25710530]

[151]. Zhao C, Deng W, Gage FH, Mechanisms and functional implications of adult neurogenesis, Cell 132 (4) (2008) 645-660. [PubMed: 18295581]

[152]. Song J, Zhong C, Bonaguidi MA, Sun GJ, Hsu D, Gu Y, Meletis K, Huang ZJ, Ge S, Enikolopov G, Deisseroth K, Luscher B, Christian KM, Ming GL, Song H, Neuronal circuitry mechanism regulating adult quiescent neural stem-cell fate decision, Nature 489 (7414) (2012) 150-154. [PubMed: 22842902]

[153]. Song J, Christian KM, Ming GL, Song H, Modification of hippocampal circuitry by adult neurogenesis, Dev. Neurobiol. 72 (7) (2012) 1032-1043. [PubMed: 22354697]

[154]. Andreotti JP, Prazeres PHDM, Magno LAV, Romano-Silva MA, Mintz A, Birbrair A, Neurogenesis in the postnatal cerebellum after injury, Int. J. Dev. Neurosci. (2018).

[155]. Song J, Sun J, Moss J, Wen Z, Sun GJ, Hsu D, Zhong C, Davoudi H, Christian KM, Toni N, Ming GL, Song H, Parvalbumin interneurons mediate neuronal circuitry-neurogenesis coupling in the adult hippocampus, Nat. Neurosci. 16 (12) (2013) 1728-1730. [PubMed: 24212671]

[156]. Song J, Olsen RH, Sun J, Ming GL, Song H, Neuronal circuitry mechanisms regulating adult mammalian neurogenesis, Cold Spring Harb. Perspect. Biol. 8 (8) (2016). 
[157]. Howell OW, Scharfman HE, Herzog H, Sundstrom LE, Beck-Sickinger A, Gray WP, Neuropeptide $\mathrm{Y}$ is neuroproliferative for post-natal hippocampal precursor cells, J. Neurochem. 86 (3) (2003) 646-659. [PubMed: 12859678]

[158]. Howell OW, Silva S, Scharfman HE, Sosunov AA, Zaben M, Shtaya A, McKhann G 2nd, Herzog H, Laskowski A, Gray WP, Neuropeptide Y is important for basal and seizure-induced precursor cell proliferation in the hippocampus, Neurobiol. Dis. 26 (1) (2007) 174-188. [PubMed: 17317195]

[159]. Cardoso A, Freitas-da-Costa P, Carvalho LS, Lukoyanov NV, Seizure-induced changes in neuropeptide Y-containing cortical neurons: potential role for seizure threshold and epileptogenesis, Epilepsy Behav.: E\&B 19 (4) (2010) 559-567.

[160]. Zaben M, Sheward WJ, Shtaya A, Abbosh C, Harmar AJ, Pringle AK, Gray WP, The neurotransmitter VIP expands the pool of symmetrically dividing postnatal dentate gyrus precursors via VPAC2 receptors or directs them toward a neuronal fate via VPAC1 receptors, Stem Cells 27 (10) (2009) 2539-2551. [PubMed: 19650041]

[161]. Bao H, Asrican B, Li W, Gu B, Wen Z, Lim SA, Haniff I, Ramakrishnan C, Deisseroth K, Philpot B, Song J, Long-range GABAergic inputs regulate neural stem cell quiescence and control adult hippocampal neurogenesis, Cell Stem Cell 21 (5) (2017) 604-617 e5. [PubMed: 29100013]

[162]. Romero-Grimaldi C, Moreno-Lopez B, Estrada C, Age-dependent effect of nitric oxide on subventricular zone and olfactory bulb neural precursor proliferation, J. Comp. Neurol. 506 (2) (2008) 339-346. [PubMed: 18022945]

[163]. Tong CK, Chen J, Cebrian-Silla A, Mirzadeh Z, Obernier K, Guinto CD, Tecott LH, GarciaVerdugo JM, Kriegstein A, Alvarez-Buylla A, Axonal control of the adult neural stem cell niche, Cell Stem Cell 14 (4) (2014) 500-511. [PubMed: 24561083]

[164]. Paez-Gonzalez P, Asrican B, Rodriguez E, Kuo CT, Identification of distinct ChAT( + ) neurons and activity-dependent control of postnatal SVZ neurogenesis, Nat. Neurosci. 17 (7) (2014) 934 942. [PubMed: 24880216]

[165]. Lao CL, Lu CS, Chen JC, Dopamine D3 receptor activation promotes neural stem/progenitor cell proliferation through AKT and ERK1/2 pathways and expands type-B and -C cells in adult subventricular zone, Glia 61 (4) (2013) 475-489. [PubMed: 23322492]

[166]. Kim Y, Wang WZ, Comte I, Pastrana E, Tran PB, Brown J, Miller RJ, Doetsch F, Molnar Z, Szele FG, Dopamine stimulation of postnatal murine subventricular zone neurogenesis via the D3 receptor, J. Neurochem. 114 (3) (2010) 750-760. [PubMed: 20477937]

[167]. Winner B, Desplats P, Hagl C, Klucken J, Aigner R, Ploetz S, Laemke J, Karl A, Aigner L, Masliah E, Buerger E, Winkler J, Dopamine receptor activation promotes adult neurogenesis in an acute Parkinson model, Exp. Neurol. 219 (2) (2009) 543-552. [PubMed: 19619535]

[168]. Berg DA, Belnoue L, Song H, Simon A, Neurotransmitter-mediated control of neurogenesis in the adult vertebrate brain, Development 140 (12) (2013) 2548-2561. [PubMed: 23715548]

[169]. Perez-Villalba A, Sirerol-Piquer MS, Belenguer G, Soriano-Canton R, Munoz-Manchado AB, Villadiego J, Alarcon-Aris D, Soria FN, Dehay B, Bezard E, Vila M, Bortolozzi A, Toledo-Aral JJ, Perez-Sanchez F, Farinas I, Synaptic regulator alpha-synuclein in dopaminergic fibers is essentially required for the maintenance of subependymal neural stem cells, J. Neurosci. 38 (4) (2018) 814-825. [PubMed: 29217686]

[170]. Ltic S, Perovic M, Mladenovic A, Raicevic N, Ruzdijic S, Rakic L, Kanazir S, Alpha-synuclein is expressed in different tissues during human fetal development, J. Mol. Neurosci. 22 (3) (2004) 199-204. [PubMed: 14997013]

[171]. Paul A, Chaker Z, Doetsch F, Hypothalamic regulation of regionally distinct adult neural stem cells and neurogenesis, Science 356 (6345) (2017) 1383-1386. [PubMed: 28619719]

[172]. Andreotti JP, Lousado L, Magno LAV, Birbrair A, Hypothalamic neurons take center stage in the neural stem cell niche, Cell Stem Cell 21 (3) (2017) 293-294. [PubMed: 28886362]

[173]. Allen RG, Peng B, Pellegrino MJ, Miller ED, Grandy DK, Lundblad JR, Washburn CL, Pintar $\mathrm{JE}$, Altered processing of pro-orphanin $\mathrm{FQ}$ /nociceptin and pro-opiomelanocortin-derived peptides in the brains of mice expressing defective prohormone convertase 2, J. Neurosci. 21 (16) (2001) 5864-5870. [PubMed: 11487609] 
[174]. Lindsey BW, Tropepe V, A comparative framework for understanding the biological principles of adult neurogenesis, Prog. Neurobiol. 80 (6) (2006) 281-307. [PubMed: 17218052]

[175]. Bergmann O, Spalding KL, Frisen J, Adult neurogenesis in humans, Cold Spring Harb. Perspect. Biol. 7 (7) (2015) a018994.

[176]. Quinones-Hinojosa A, Sanai N, Soriano-Navarro M, Gonzalez-Perez O, Mirzadeh Z, GilPerotin S, Romero-Rodriguez R, Berger MS, Garcia-Verdugo JM, Alvarez-Buylla A, Cellular composition and cytoarchitecture of the adult human subventricular zone: a niche of neural stem cells, J. Comp. Neurol. 494 (3) (2006) 415-434. [PubMed: 16320258]

[177]. Ernst A, Alkass K, Bernard S, Salehpour M, Perl S, Tisdale J, Possnert G, Druid H, Frisen J, Neurogenesis in the striatum of the adult human brain, Cell 156 (5) (2014) 1072-1083. [PubMed: 24561062]

[178]. Bergmann O, Liebl J, Bernard S, Alkass K, Yeung MS, Steier P, Kutschera W, Johnson L, Landen M, Druid H, Spalding KL, Frisen J, The age of olfactory bulb neurons in humans, Neuron 74 (4) (2012) 634-639. [PubMed: 22632721]

[179]. Batailler M, Droguerre M, Baroncini M, Fontaine C, Prevot V, Migaud M, DCX-expressing cells in the vicinity of the hypothalamic neurogenic niche: a com-parative study between mouse, sheep, and human tissues, J. Comp. Neurol. 522 (8) (2014) 1966-1985. [PubMed: 24288185]

[180]. Nogueira AB, Sogayar MC, Colquhoun A, Siqueira SA, Nogueira AB, Marchiori PE, Teixeira MJ, Existence of a potential neurogenic system in the adult human brain, J. Transl. Med. 12 (2014) 75. [PubMed: 24655332]

[181]. Spalding KL, Bergmann O, Alkass K, Bernard S, Salehpour M, Huttner HB, Bostrom E, Westerlund I, Vial C, Buchholz BA, Possnert G, Mash DC, Druid H, Frisen J, Dynamics of hippocampal neurogenesis in adult humans, Cell 153 (6) (2013) 1219-1227. [PubMed: 23746839]

[182]. Knoth R, Singec I, Ditter M, Pantazis G, Capetian P, Meyer RP, Horvat V, Volk B, Kempermann $\mathrm{G}$, Murine features of neurogenesis in the human hippo-campus across the lifespan from 0 to 100 years, PLoS One 5 (1) (2010) e8809. [PubMed: 20126454]

[183]. Sorrells SF, Paredes MF, Cebrian-Silla A, Sandoval K, Qi D, Kelley KW, James D, Mayer S, Chang J, Auguste KI, Chang EF, Gutierrez AJ, Kriegstein AR, Mathern GW, Oldham MC, Huang EJ, Garcia-Verdugo JM, Yang Z, Alvarez-Buylla A, Human hippocampal neurogenesis drops sharply in children to undetectable levels in adults, Nature 555 (7696) (2018) 377-381. [PubMed: 29513649]

[184]. Boldrini M, Fulmore CA, Tartt AN, Simeon LR, Pavlova I, Poposka V, Rosoklija GB, Stankov A, Arango V, Dwork AJ, Hen R, Mann JJ, Human hippocampal neurogenesis persists throughout aging, Cell Stem Cell 22 (4) (2018) 589-599 e5. [PubMed: 29625071]

[185]. Kempermann G, Gage FH, Aigner L, Song H, Curtis MA, Thuret S, Kuhn HG, Jessberger S, Frankland PW, Cameron HA, Gould E, Hen R, Abrous DN, Toni N, Schinder AF, Zhao X, Lucassen PJ, Frisen J, Human adult neurogen רesis: evidence and remaining questions, Cell Stem Cell 23 (1) (2018) 25-30. [PubMed: 29681514]

[186]. Henriques F, et al., Toll-like receptor-4 disruption suppresses adipose tissue remodeling and increases survival in cancer cachexia syndrome, Sci. Rep. 8 (2018) 18024, 10.1038/ s41598-018-36626-3. [PubMed: 30575787]

[187]. Pereira LX, et al., Synthetic matrix of polyether-polyurethane as a biological platform for pancreatic regeneration, Life Sci. 176 (2017) 67-74, 10.1016/j.lfs.2017.03.015. [PubMed: 28336399]

[188]. Birbrair A, Stem cells heterogeneity, Adv. Exp. Med. Biol. (2019).

[189]. Salmina AB, Komleva YK, Lopatina OL, Birbrair A, Pericytes in Alzheimer's Disease: novel clues to cerebral amyloid angiopathy pathogenesis, Adv. Exp. Med. Biol. (2019).

[190]. Barreto RSN, et al., Pericytes in the placenta: role in placental development and homeostasis, Adv. Exp. Med. Biol. (2019). 


\section{HIGHLIGHTS}

- Neural stem cells are not equally plastic homogeneous cells, but rather a combination of distinct subpopulations.

- The cerebrospinal fluid is an essential component of the neural stem cell niche.

- $\quad$ Neural stem cells auto-regulate themselves.

- Innervations release neurotransmitters to neural stem cells, and affect neural stem cell behavior.

- The biggest challenge remains to study the neural stem cell niche in humans. 
PROLIFERATIVE ZONES

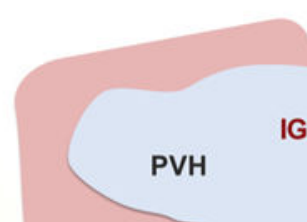

(I)

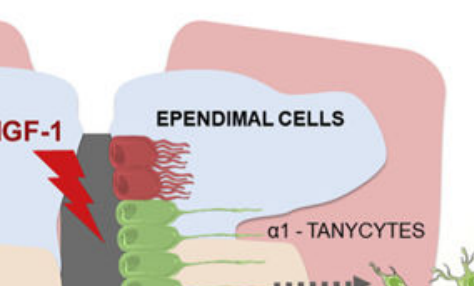

SUBTYPES OF TANYCYTES

(II) $\quad \mathrm{vmH}$

( III )

LHA

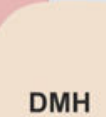

DMH

(1) DORSAL \& 2 TANYCYTES

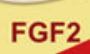

VMH

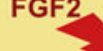

$8=$

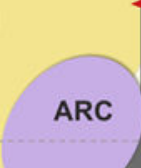

(ME)

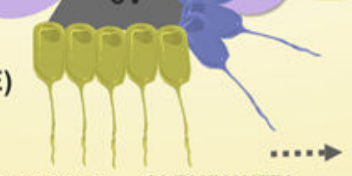

$\beta 1$ TANYCYTES

B2 TANYCYTES
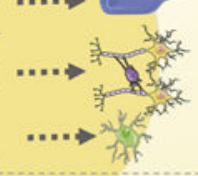

VENTRAL $\alpha 2$ - TANYCYTES

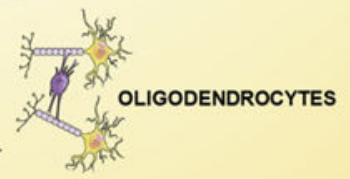

Fig. 1. Presence of neural stem cells (tanycytes) in the adult hypothalamus.

Three proliferative zones were reported in the adult hypothalamus. The first (I) proliferative zone, in the dorsal a 1 region, after a stimulus (IGF-1) can induce tanycytes to originate neurons and possibly astrocytes in the adjacent hypothalamic parenchyma. The second (II) proliferative zone, in the dorsal a 2 region, can be stimulated by FGF-2 activating the symmetric self-renewal of dorsal a 2 tanycytes or can be give origin to neurons and astrocytes; and rarely oligodendrocytes. In the third (III) proliferative zone, called "hypothalamic proliferative region", located in the adjacent median eminence (ME), tanycytes proliferate symmetrically giving rise to neurons, and possibly progenitors of oligodendrocytes. FGF-2: fibroblast growth factor type 2; IGF-1: Insulin-Like Growth Factor 1; PVH: paraventricular nucleus; LHA: lateral hypothalamic area; DMH: dorsomedial hypothalamic; VMH: ventromedial hypothalamic; ARC: arcuate nucleus; 3V: third ventricle. 


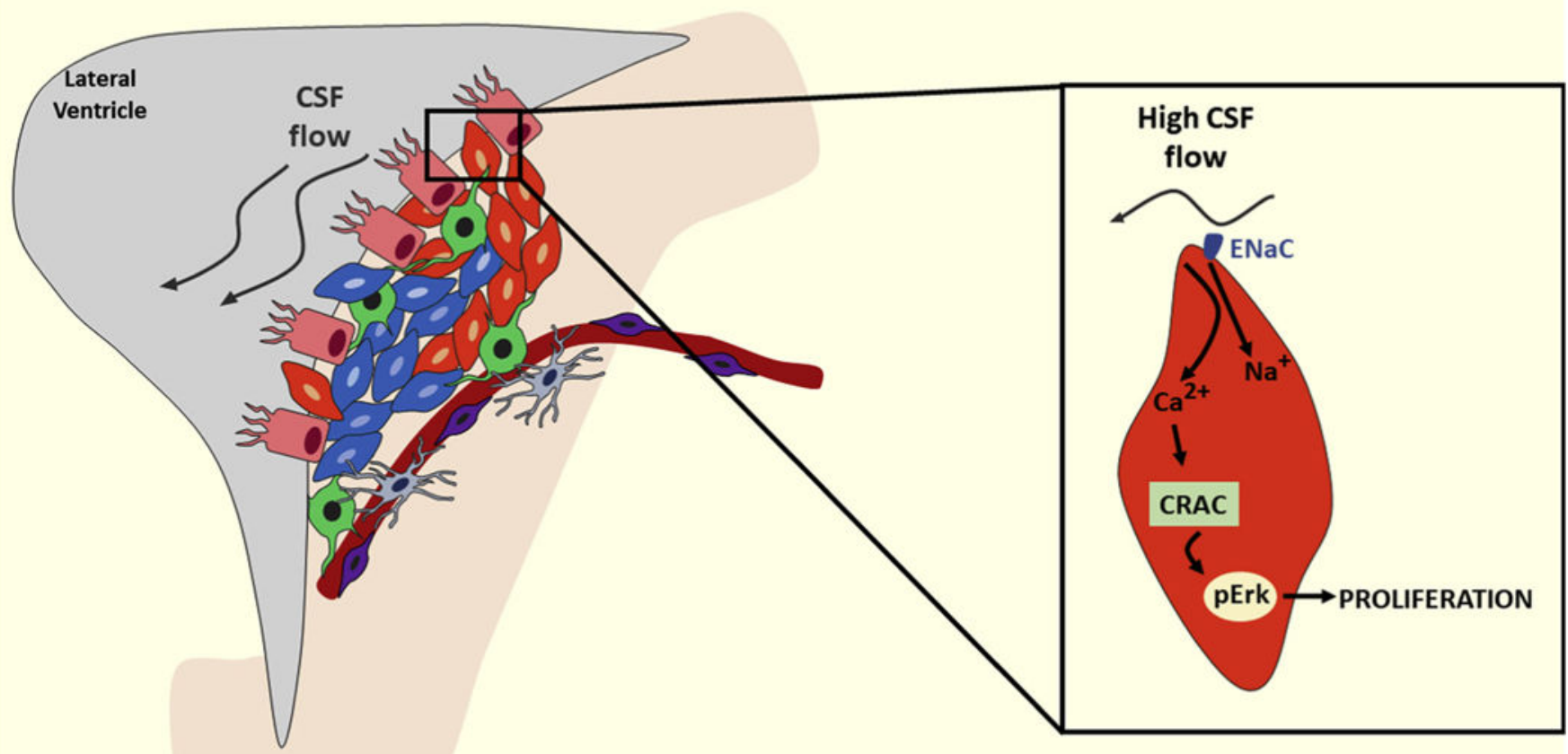

SVZ

Fig. 2.

Changes in cerebrospinal fluid flow can alter neural stem cell proliferation and neurogenesis. In the subventricular zone (SVZ) of the lateral ventricles, neural stem cells are in close contact with the cerebrospinal fluid (CSF). Alterations in the cerebrospinal fluid flow are detected by epithelial sodium channels present in these cells, which can affect their proliferation and differentiation. Epithelial sodium channel (ENaC), calcium releaseactivated channels (CRAC), phosphorylated extracellular signal-regulated kinases (pERK). 


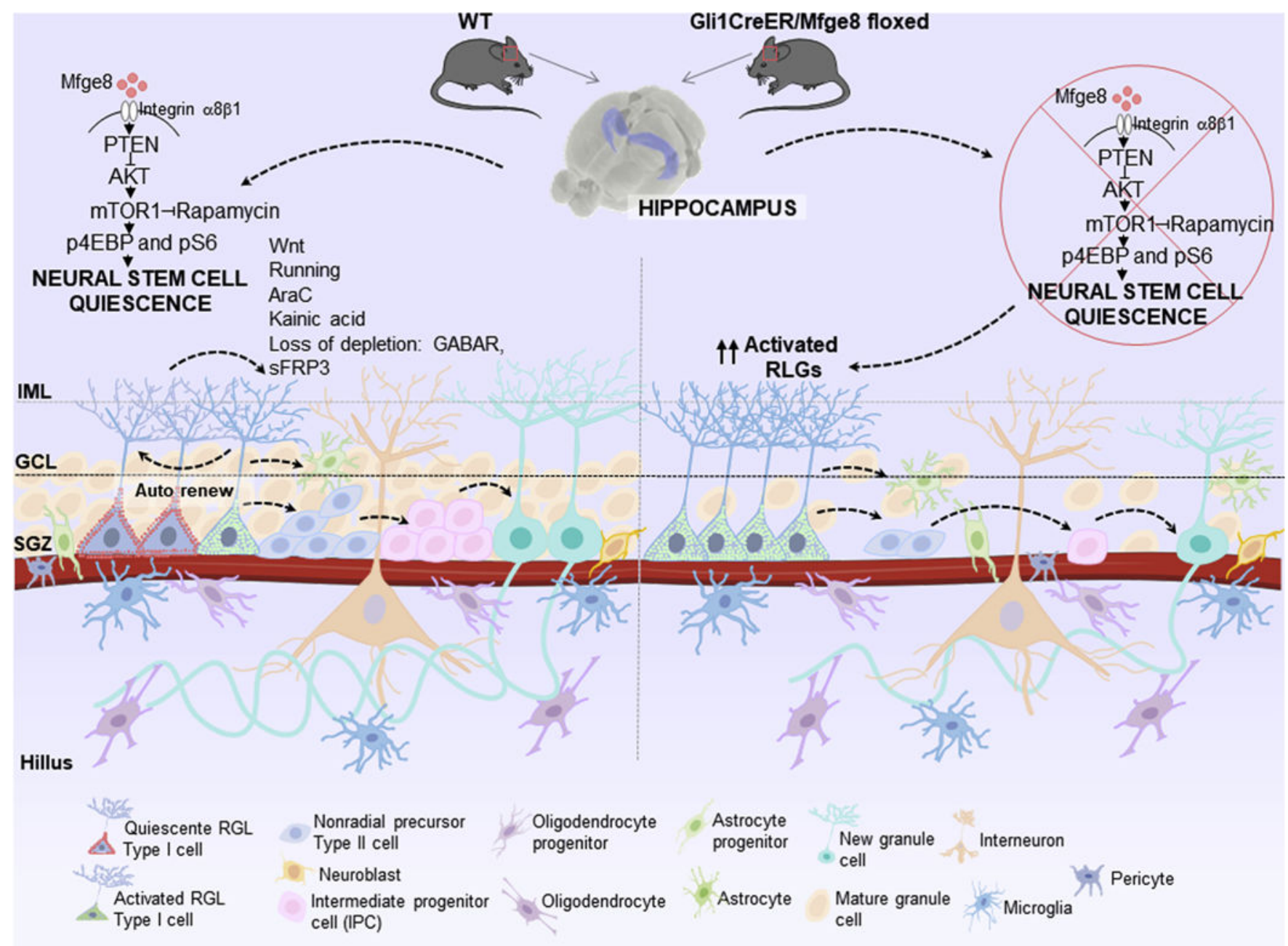

Fig. 3.

Autocrine signaling in the subgranular zone (SGZ) in the dentate gyrus. Quiescent radial glia like neural stem cells (RGLs) are activated and continuously give rise to newborn dentate granule cells. Milk fat globule-epidermal growth factor (Mfge8), also called lactadherin, is a neural stem cell enriched niche factor that maintains the neural stem cell pool in the dentate gyrus during early postnatal development and in the adulthood by promoting neural stem cell quiescence. Mfge8 is enriched in quiescent neural stem cell and regulates neural stem cell quiescence, via mTOR1 signaling, and its deletion depletes neural stem cells and decreases adult neurogenesis. 


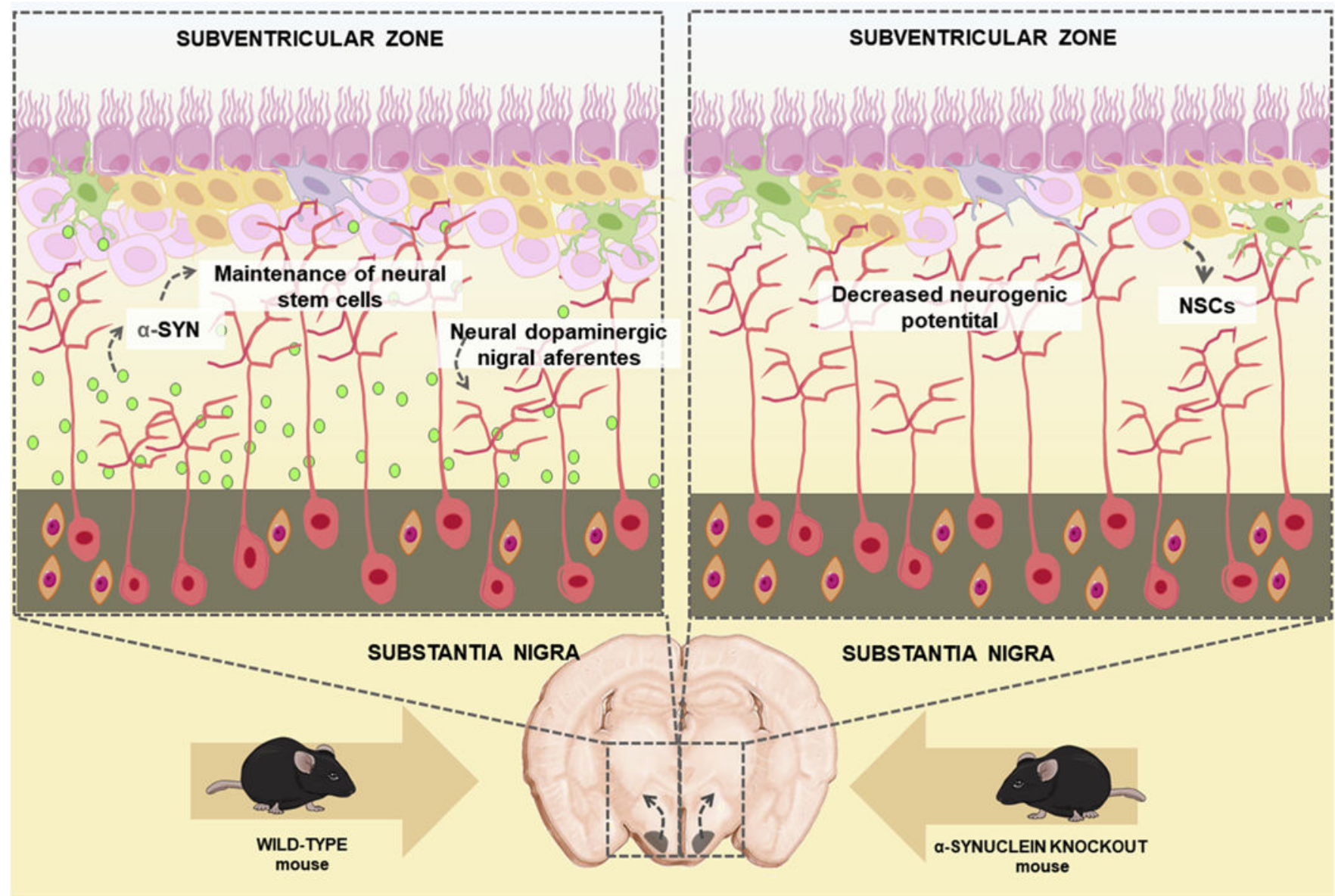

Fig. 4.

$a$-synuclein ( $a-S Y N)$ present in dopaminergic nigral afferents is essential for the normal cycling and maintenance of neural stem cells (NSCs) in the adult subventricular zone. 


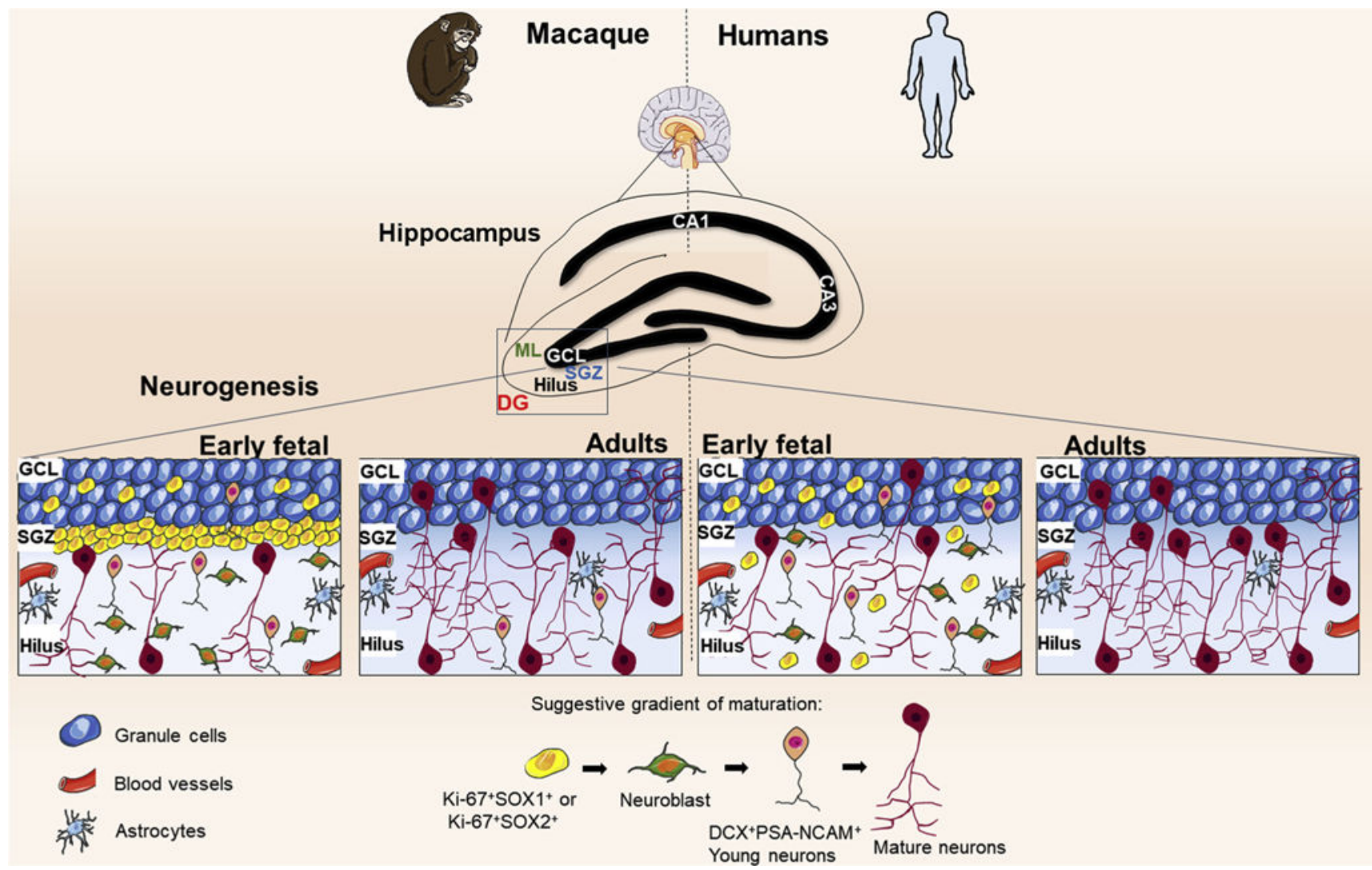

Fig. 5.

Hippocampal neurogenesis was not detected in adult humans by Sorrells et al. (2018). The study of Sorrells and colleagues suggests differences in neurogenesis among primates. In humans, in the dentate gyrus (DG), a proliferative subgranular zone (SGZ) is not formed near the granule cell layer (GCL), instead, the proliferating cells, which express progenitor stem markers, are mostly scattered in the hilus and depleted from the 7 years old. The number of young neurons, DCX + PSA-NCAM + cells, in GCL and hilus, also decrease from birth and in adult individuals, these cells are no longer found in the hippocampus. In adult humans, the predominance of morphologically mature neurons expressing PSA-

$\mathrm{NCAM}+$ and NeuN was observed. In rhesus macaque (M. mulatta) there are some differences in the process of neurogenesis. In DG the formation of a germinative proliferative subgranular zone (SGZ) is observed. The number of proliferative cells and young neurons DCX + PSA-NCAM + decreases until the 7 years old, an age in which the germ cell layer in the SGZ already becomes dispersed. A developmental normalization has shown that the decrease of young neurons in humans is more accelerated than in monkeys, which allows the identification of still rare DCX + PSA- NCAM + neurons in adult monkeys. PSA-NCAM: Polysialylated neural cell adhesion molecule; DCX: doublecortin; NeuN: neuronal nuclear antigen. 


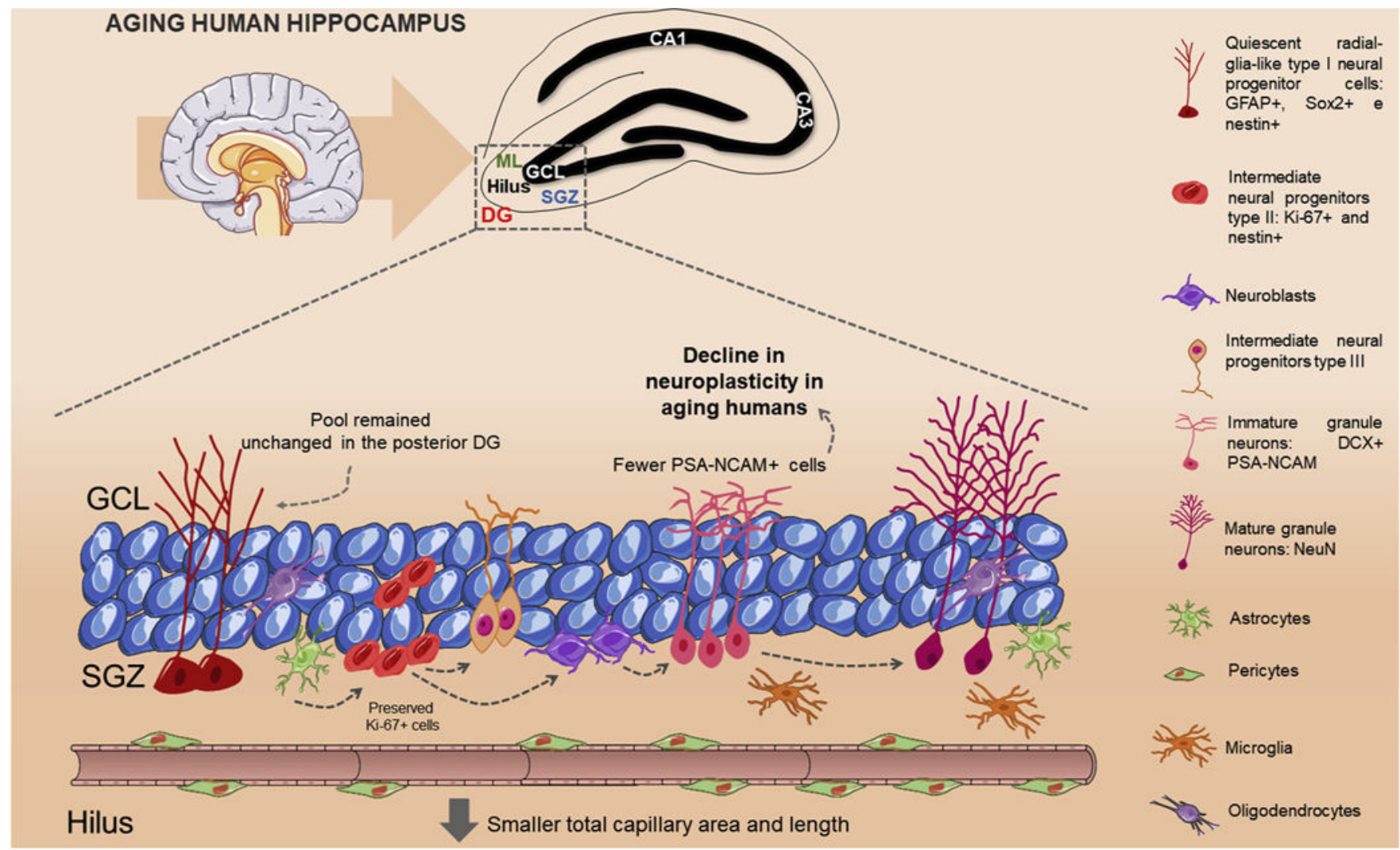

Fig. 6. Hippocampal neurogenesis continues during aging in humans.

The study of Boldrini and colleagues suggests that neurogenesis is present in the human hippocampus. PSA-NCAM was detected in cells that had morphology of intermediate neural progenitors and immature granule neurons showing that these cells remained preserved with aging. PSA-NCAM: Polysialylated neural cell adhesion molecule. 